ISSN: 2146-3042

DOI:10.25095/mufad.813411

\title{
COVID-19'un BIST İmalat Sektörü Firmalarına Olan Finansal Etkilerinin Finansal Oranlar ve İstatistiksel Tekniklerle Íncelenmesi*
}

\begin{tabular}{|c|c|}
\hline & \\
\hline \multicolumn{2}{|r|}{ ÖZET } \\
\hline \multicolumn{2}{|c|}{ 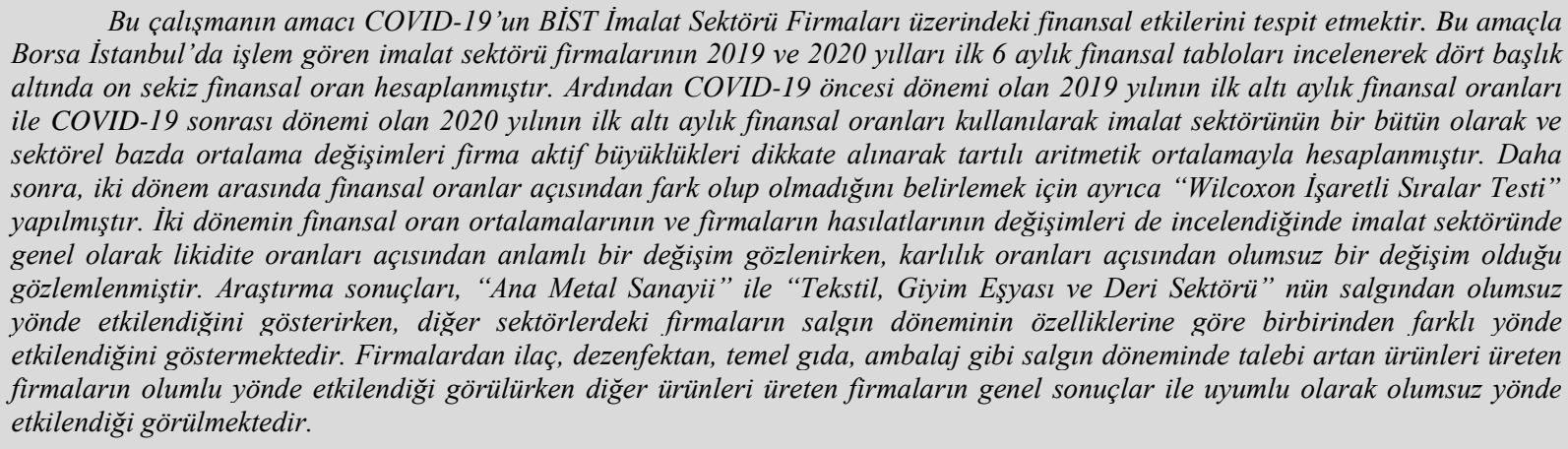 } \\
\hline \multirow[t]{2}{*}{ Testi } & Anahtar Kelimeler: Finansal Oranlar, \\
\hline & JEL Sinıflandırması: M49, M40, C02 \\
\hline
\end{tabular}

\section{Investigation of Financial Impacts of COVID-19 on BIST Manufacturing Sector Firms by Financial Ratios and Statistical Techniques}

\section{ABSTRACT}

The purpose of this study is to determine the financial effects of COVID-19 on BIST Manufacturing Sector Firms. For this purpose, 18 financial ratios were calculated under 4 titles by examining the financial statements of the Manufacturing Sector Companies traded in Borsa Istanbul, the first six months of 2019 and 2020. Then, using the financial ratios of the first six months of 2019, which is the period before COVID-19, and the financial ratios of the first six months of 2020, which is the period after COVID-19, the average changes of the manufacturing sector as a whole and on a sectoral basis were calculated with weighted arithmetic average, taking into account the asset sizes of the companies. Then, to determine whether there was a difference between the two periods in terms of financial rates, the Wilcoxon Sign test was also used. When the changes in the financial ratio means of the two periods and the revenues of the firms were examined, it was observed that a significant change was observed in the manufacturing sector in terms of "Liquidity Ratios", while a negative change was observed in terms of "Profitability Ratios". In addition, the research results indicate that while the pandemic negatively affected the Main Metal Industry and the Textile, Clothing and Leather Industry, companies in other sectors were affected differently according to the characteristics of the pandemic period. While it was observed that companies producing products such as pharmaceuticals, disinfectants, basic food and packaging, whose demand increased during the pandemic period, were positively affected, it was observed that companies producing other products were negatively affected in line with the general results.

Keywords: Financial Ratios, Manufacturing Sector, COVID-19, Nonparametric Tests, Wilcoxon Signed Ranks Test.

Jel Classification: M49, M40, C02.

\footnotetext{
* Makale Gönderim Tarihi: 20.10.2020, Makale Kabul Tarihi: 26.12.2020 , Makale Türü: Nicel Araştırma

** Dr. Öğr. Üyesi, Düzce Üniversitesi, Akçakoca Meslek Yüksekokulu, serkanyucel@duzce.edu.tr, ORCID: 0000-0002-8744-5779.

*** Dr. Öğr. Üyesi, Düzce Üniversitesi, İşletme Fakültesi, ismaildurak@duzce.edu.tr, ORCID: 0000-0002-88989639 .
} 


\section{GIIRIŞ}

Geçmişten günümüze insanlığı başta sağlık olmak üzere birçok yönden tehdit eden çeşitli olaylar meydana gelmiştir. Bu olayların sosyal ve ekonomik açıdan birçok etkileri olmuştur. 2019 yılının sonu itibariyle bunlardan biri olan korona virüs pandemisi ile karş1 karşıya gelen insanoğlunun, yirmi birinci yüzyıldaki teknolojik ve bilimsel gelişmişliğin verdiği beklentiyle bu küresel tehdide karşı hızlı ve etkili cevap vererek bu salgını kısa sürede önleyebileceği düşünülüyordu (Nueangnong vd., 2020: 1). Fakat bunun aksine, ilk olarak yerel çapta aniden ortaya çıkan korona virüs, küreselleşmenin verdiği hıza ayak uydurarak çok kısa bir sürede yayılarak global bir salgına dönüştü. Ayrıca, geçmişte meydana gelen çok büyük salgınlar kadar, hatta bu salgınların neden olduğu devasa yıkımlardan daha fazla zararlı sonuçlara yol açmaya doğru hareket ettiği ve gelecekte ortaya çıkacak önemli davranışsal ve ekonomik değişimlere yol açmasının beklendiği açıkça söylenebilir (Berchin vd., 2020: 2).

COVID-19 ismiyle de anılan bu virüs ilk olarak Çin' de yer alan Hubei bölgesinde 2019 sonlarına doğru ortaya çıkmıştır. Çin'den sonra, 2020 Ocak' tan itibaren İran'da görülen bu virüs ardından İtalya, İspanya' da görülmeye başlanmıştır. Avrupa' da ilk vaka tespit edildikten sonra ise bir ay gibi kısa bir sürede nerdeyse tüm Avrupa kıtasına yayılmıştır. Salgının çok hızlı bir seyir izlemesinden dolayı 11 Mart 2020 tarihinde Dünya Sağlık Örgütü (DSÖ) korona virüs hastalığını pandemi olarak ilan etmiştir (WHO, 2020). Korona virüsün çok büyük tahribata neden olduğu ülkelerin başında gelen ABD' de vaka sayısı Ekim 2020 itibariyle 16,8 milyona, dünya genelinde ise 73,6 milyona ulaşırken, korona virüsten ölenlerin sayıs1 ise 1,64 milyonu geçmiştir (Worldometers, 2020).

COVID-19 gibi öngörülemeyen salgınlar beraberlerinde başta ekonomik ve finansal olmak üzere birçok farklı krizi de ortaya çıkarmaktadır. Birbirine yakın iki kavram olmasına karşın ekonomik kriz, büyüme hızında düşüş veya bir durgunluk (negatif büyüme oranı) gibi ekonomik dinamiklerde önemli bozulmanın ortaya çıkması iken, finansal kriz, finansal piyasalarda meydana gelen bilgi akışı bozulması ve finans piyasalarının görevlerini yerine getirememesi şeklinde tanımlanabilir (Sakarya, 2006: 52). Bu tür durumlarda, kriz yönetimi anlayışının gereği olarak; salgın, doğal afet, anarşi, terör, siyasi ve ekonomik problemler gibi oldukça fazla risk barındıran ve tahmin edilmesi çok zor olan felaketlerin ortadan kaldırılması veya hasarının en aza düşürülmesi amaçlanmaktadır.

Öte yandan, küresel çapta ve birçok alanda yıkımlara neden olan korona virüs pandemisinin 2007-2009 küresel finansal krizinden çok daha fazla olumsuz etkilerinin olduğu İktisadi İşbirliği ve Gelişme Teşkilatı (OECD) tarafından belirtilmektedir (OECD, 2020). Bu olumsuz etkinin, hizmet sektöründen uluslararası ticarete, turizmden imalata ve havayolundan dünyadaki diğer birçok sektöre kadar küresel ekonomiyi kapsadığı görülmektedir. Özellikle imalat sektörü gıdadan, metale, kâğıttan taş ve taşa dayalı ürünlere, tekstilden kimya ilaç sanayisine kadar birçok alt sektörden oluştuğundan imalat sektöründe meydana gelen bir değişim geniş bir etki alanı bulmaktadır. Ayrıca, korona virüs tüm ülkeler için yıkıcı etkilere sahip olmakla beraber az gelişmiş ya da gelişmekte olan ülkelerde neden olduğu tahribat ve etkileme düzeyi gelişmiş ülkelere nispeten çok daha hızlı ve fazladır (OECD, 2020).

Türkiye'de ilk korona virüs vakası 11.03.2020 tarihinde tespit edilmiştir. Bu tarihten sonra ülke tarihinde ilk kez sınırların kapanması, havayollarının tüm uçaklarını yere indirmesi, seyahatin yasaklanması, sokağa çıkma yasakları, fabrikalarda üretimlerin durması 
vb. uygulamalar görülmüştür. Bu dönemde COVID-19 ile ilgili Türkiye'de yapılan çalışmalar incelendiğinde, salgının çeşitli alan ve sektörlere olan etkisi üzerine çeşitli araştırmalar yapıldığ 1 dikkat çekmektedir. Bu çalışmalara "literatür incelemesi" bölümünde detaylı olarak yer verilmiştir. Ancak, literatür incelemesi bölümünde görüleceği üzere COVID-19’un Türk imalat sektöründe faaliyet gösteren firmalar üzerine olan finansal etkilerini doğrudan inceleyen bir çalışma tespit edilememiştir. Bu çerçevede bu çalışmanın amacı COVID-19'un BİST İmalat Sektörü'nde faaliyet gösteren firmalar üzerine olan etkilerini firmaların finansal tablolarından elde edilen finansal oranlar yardımı ile tespit etmektir.

\section{LITERATÜR TARAMASI}

Şirketlerin finansal yapısını, karlılık düzeyini, krizlerden etkilenme düzeyini vb. incelemek için en sık kullanılan yöntemlerden biri oran analizidir. Oran analizi, şirketlerin durumu hakkında diğer analiz tekniklerine göre daha detaylı bilgi sağlayabildiği için finansal analiz teknikleri arasında en yaygın kullanılan analiz tekniği olarak kabul edilmektedir (Bakır ve Şahin, 2009:132). Oran analizi hesap veya hesap grupları arasında sayısal ilişkiler oluşturularak, işletmenin; finansal yapısı, kârlılık, faaliyet etkinliği konularında yargıya ulaşmamızı sağlar (Balcı, 2012: 4689). Literatürde finansal oranların; krizlerin firmalara olan etkilerini tespit etmek, firmalar arasındaki farklılıkları, firmaların finansal yapılarını ve likidite düzeylerini incelemek vb. birçok amaçla kullanıldığı görülmektedir. Aşağıda bu makaledeki araştırma yöntemini kullanarak yapılan çalışmalar ve COVID-19'in ekonomik etkileri ile ilgili çalışmalara ayrı başlıklar halinde yer verilmiştir.

\subsection{Krizlerin Finansal Oranlara Olan Etkilerini İnceleyen Çalışmalar}

Türkiye'de finansal krizlerin firmalara olan etkilerini finansal oranlar yardımı ile inceleyen çalışmalardan bazıları şu şekildedir;

Müslümov ve Karataş (2001), Türkiye'deki tekstil, gıda ve çimento sektörleri işletmelerinin Güneydoğu Asya krizinden nasıl etkilendiğini incelemişlerdir. Araştırma sonucunda, ihracata yönelik Türk tekstil sektörünün karlılık marjlarının önemli ölçüde azaldığ 1 tespit edilirken, gıda ve çimento sektörlerinde mali boyutlarda istatistiksel olarak önemli bir değişiklik tespit edilmemiştir.

Bu çalışmadan sonra 2001 ve 2008 krizlerinin şirketlere olan etkilerini finansal oranlar yardımı ile inceleyen çalışmalar göze çarpmaktadır. Bu çalışmalardan Uyar ve Okumuş (2010) İMKB'de işlem gören üretim şirketlerinin küresel ekonomik krizden etkilenme durumlarını finansal oranlar aracılığıyla araştırmışlardır. Araştırma sonuçları likidite oranlarının düşmesinin kısa vadeli borç ödeme kabiliyetinin zayıfladığına işaret ettiği, karlılık oranlarının negatif olmasının ise şirketlerin çoğunluğunun kriz döneminde zarar ettiğinin göstergesi olduğu belirtilmiştir.

Abdioğlu vd. (2010), 2001 ekonomik kriziyle 2008 küresel ekonomik krizin İMKB imalat sektöründeki şirketlerin mali yapılarına etkilerini incelemişlerdir. Araştırma sonucunda, şirketlerin finansal oranlarından; likidite oranları, mali yapı oranları, faaliyet oranları ve borsa performans oranları arasında incelenen dönemler için istatistiksel olarak anlamlı farklılık belirlenmiştir. Şirketlerin karlılık oranlarında ise her iki kriz dönemi arasında istatistiksel olarak anlamlı bir farklılık tespit edilmemiştir. Benzer şekilde İskenderoğlu ve 
Karakozak (2013) İMKB (BIST)'de faaliyet gösteren üretim (imalat) şirketleri üzerine krizlerin etkisini incelemişlerdir. Araştırma sonuçları, işletmelerin iflas risklerinin belirleyicisi olan Altman Z-skor değerlerinin işletmelerin 2008 yilı ilk çeyreğinden 2009 yilı son çeyreğine kadar iflas risklerinde artış olduğunu göstermiştir.

Çalışkan vd. (2011) İMKB'de işlem gören gıda şirketlerini incelemişlerdir. Çalışma sonucunda, işletmelerin kriz döneminde, nakit oranlarında azalmanın yaşandığı kanısına varılmıştır. Topaloğlu (2014) BIST Metal Eşya, Makina Endeksi’nde faaliyet gösteren şirketlere finansal krizlerin etkisini araştırmışlardır. Çalışma sonucunda, birçok firmanın 2000-2012 dönemindeki finansal performans puanlarında ve buna bağlı olarak ortaya çıkan sıralamada dalgalanmalar belirlenmiştir. Ayrica, 2008 krizi nedeniyle oluşan kırılganlığın, 2001 krizine oranla daha düşük seviyede olduğu belirtilmiştir.

Vural ve Uçar (2017), turizm şirketlerinin 2001 ve 2008 krizlerinden nasıl etkilendiğini finansal oranlar yardımı ile tespit etmek için yaptıkları araştırma sonucunda, 2001 Ulusal krizinin 2008 küresel kriziyle karşılaştırıldığında, finansal durum açısından turizm sektörünü daha fazla etkilediği ve turizm firmalarının genelinin ulusal kriz döneminde piyasa duyarlılığının daha fazla olduğunun belirlendiği ifade edilmiştir.

Gider (2011), özel bir hastanenin 2001 krizinden nasıl etkilendiğini araştırmıştır. Araştırma soncunda, Acıbadem Sağlık Hizmetleri ve Ticaret A.Ş.'nin Kasım 2000 ve Şubat 2001 ekonomik krizlerinden olumsuz yönde etkilendiği, ancak bu olumsuzluğun takip eden yıllarda sürmediği sonucuna varılmıştır.

$\mathrm{Bu}$ çalışmalar haricinde yakın zamanda yapılmış diğer çalışmalar ise şu şekildedir: Karadeniz (2019) çalışmasında, Türkiye ile Rusya arasında yaşanan uçak krizinin BIST Turizm Şirketleri üzerindeki finansal etkilerini belirlemek amacıyla şirketlerin 2014-2015 yılları ve kriz sonrasındaki 2016-2017 yıllarına ait finansal oranları arasında bir karşılaştırma yapmıştır. Çalışma sonucunda, kriz sonrası dönemde likidite oranlarında, alacak devir hızında, net kâr marjı ve öz sermaye karlılık oranlarında düşüş yaşandığı, buna karşın toplam ve kısa vadeli kaldıraç oranlarında, aktif devir hızında, stok devir hızında, aktif karlılık oranında ve fiyat kazanç oranında yükselme yaşandığı belirlenmiş̧tir. Çalış ve Çakır (2019) çalışmalarında 2014 yllı ve sonrasında meydana gelen finansal dalgalanmaların inşaat firmalarının finansal performansına etkisinin olup olmadığını incelemiştir. Bu amaçla firmaların 2014-2019 yıllarına ait finansal oranları arasında karşılaştırma yapılmış̧ır. Araştırma sonucuna göre, finansal dalgalanmaların inşaat firmaları üzerine özellikle borçlanma yapılarında olumsuz etkiye neden olduğu ve karlılık durumlarını da olumsuz etkilediği görülmüştür.

\subsection{Finansal Oranların Sektörlere Göre Farklılaşmasını İnceleyen Çalışmalar}

Finansal oranların sektörlere göre farklılaşmasını inceleyen birçok çalışma yapılmış olup bu çalışmalardan bazıları şu şekildedir:

Benli (2005) araştırmasında, İstanbul Menkul Kıymetler Borsası'nda (IMKB) faaliyet gösteren 145 sanayi işletmesini 2002 yılı verilerinden yola çıkarak Çok Değişkenli Varyans Analizi ile alt sektörlerin finansal oranlarının değişimini test etmiş, çalışmanın sonucunda finansal oranların sanayi alt dallarına göre farklılaştığını ortaya çıkarmıştır. Ekşi ve Akçi 
(2009), Türkiye'de İMKB'de işlem gören 158 şirketin 2006 yılı mali tablolarından hesapladıkları oranlar ile şirketlerin bulunduğu imalat sanayi alt sektörlerinde finansal oranların değişimini incelemişlerdir. Çalışmada mali yapı ve kârlılık oranlarının sanayi alt sektörleri bazında farklılaştığını, likidite oranlarının alt sektörler itibariyle çok fazla farklılık göstermediğini tespit etmişlerdir.

Hacıevliyagil ve Şit (2016), çalışmalarında T.C. Bilim, Sanayi ve Teknoloji Bakanlığı'nın “Girişimci Bilgi Sistemi”nden aldıkları şirketlerin 2006-2013 yılları arasındaki oranlarını incelemişler, çalışma sonucunda, imalat sektörüne ait alt sektörde faaliyet gösteren firmalar arasında finansal oranlarda nakit oranı haricinde diğer oranlarda anlamlı farklılık bulunmadığını tespit etmişlerdir. Bunların haricinde Karadeniz vd. (2015) "Konaklama ve Yiyecek Hizmeti Faaliyetleri Alt Sektörü"ndeki küçük, orta ve büyük ölçekli işletmelerin finansal oranlarının birbirinden farklılaştığını tespit etmişlerdir.

Akaytay vd. (2015), TCMB sektör bilançoları yardımıyla üretim, ticaret ve hizmet faaliyet alanları arasında finansal oranlar açısından farklılık olup olmadığını tespit etmeyi amaçladıkları çalışmalarında faaliyet alanlarına göre finansal oranlarda farklılıklar bulunduğunu, özellikle hizmet sektörü firmalarının faaliyet oranları açısından diğer sektörlere göre ciddi farklılık gösterdiğini tespit etmişlerdir.

\subsection{COVİD-19'un Ekonomik ve Finansal Etkilerini İnceleyen Çalışmalar}

COVID-19'un ortaya çıkışından sonra farklı açılardan birçok çalışma yapılmış olup, ülke ekonomilerine ve firmalara olan finansal etkilerini inceleyen çalışmalardan tespit edilebilenleri aşağıdaki gibidir:

Gürsoy vd. (2020) COVID-19' un finansal göstergeler üzerine etkisini incelediği çalışmasında Korona virüs salgını ile finansal göstergeler arasında bir nedensellik ilişkisinin olup olmadığına bakmıştır. Virüsün ilk olarak görüldüğü Çin in gösterge pay piyasası SSEC endeksinin bağımlı değişken, altın, brent petrol, bitcoin ve VIX endeksi verilerinin ise bağımsız değişken olarak ele alındığı çalışma sonuçlarına göre, SSEC endeksi ile Altın ve VIX (korku endeksi) arasında bir nedensellik ilişkisine rastlanmıştır. Bu bağlamda, SSEC endeksinden Altına doğru tek yönlü nedensellik elde edilirken, VIX (korku endeksi) ile ise iki yönlü bir nedensellik ilişkisinin olduğu sonucuna ulaşılmıştır.

Uluslararası bir çalışma yapan Zeren ve Hızarcı (2020), COVID-19 virüsünün en sık görüldüğü ülkelerden Çin, Güney Kore, İtalya, Fransa, Almanya ve İspanya ile ilgili yaklaşık iki aylık verileri kullanarak ekonometrik bir analiz yapmıştır. Elde edilen sonuçlara göre, toplam ölüm referans alınarak incelenen bütün borsalar uzun vadede birlikte hareket etmektedir. Toplam vakalar ise Çin, Güney Kore, İspanya ile bütünleşik bir ilişki içinde olduğu görülürken, İtalya, Fransa ve Almanya ile eş bütünleşik olmadığı sonucuna varılmıştır. Yatırımcıların ise borsa yatırımlarından kaçınarak altın piyasalarına, sanal paraya, türev piyasalara ve COVID-19'un nispeten nadir görüldüğü ülkelerin hisse senedi piyasalarına yönelmesi uygun olacağı belirtilmiştir.

Yukarıdaki çalışmalar COVID-19'un ülke düzeyindeki ekonomik etkilerini incelemiştir. Bunların haricinde doğrudan firmalar üzerindeki finansal etkilerini inceleyen çalışmalar ise şu şekildedir: 
$\mathrm{Bu}$ konuda en çok COVID-19'un turizm sektörü üzerine olan etkilerini inceleyen çalışmalar olduğu göze çarpmaktadır. Bu çalı̧̧malardan Demir vd. (2020) ile İbiş (2020) çalı̧̧alarında, Turizm firmalarının üst düzey yöneticileri/sahipleriyle yapmış olduğu görüş̧meler ile COViD-19'un etkilerini tespit etmeye çalışmış̧ır. Çıtak ve Çalış (2020), salgının Turizm Sektörüne olan finansal etkilerini Dünya Turizm ve Seyahat Konseyi (WTTC) ve Türkiye İstatistik Kurumu (TÜİK) gibi kuruluşlardan aldığı veriler ile tespit etmeye çalışmıştır. Bahar ve Çelik (2020), Çıtak ve Çalış (2020)'in çalışmasına benzer şekilde OECD, TUiK, TÜRSAB (Türkiye Seyahat Acentaları Birliği) gibi kuruluşlardan aldığı veriler ile salgının turizm sektörü üzerine olan etkilerini tespit etmeye çalışmıştır. Bu çalışmaların hepsinde de birbirine benzer şekilde COVID-19'un turizm sektörünü olumsuz yönde etkilediği sonucuna ulaşılmıştır.

Öztürk vd. (2020) COVID-19' un hisse senedi piyasasindaki tüm sektörlere olan etkisini bir bütün olarak değerlendirdikleri çalışmalarında salgından en fazla olumsuz yönde etkilenen sektörlerin metal ürünleri ve makine sektörü olduğu sonucuna varmışlardır. Bu sektörlerden sonra, sırayla spor, bankacılık ve sigortacilık sektörlerin daha sonra en çok olumsuz etkilenen sektörler olduğu, en az etkilenen sektörlerin ise gıda, satış ve gayrimenkul yatırım, toptan-perakende sektörleri olduğu sonucuna ulaşılmışlardır.

Yukarıdaki çalışmalardan hiçbirinde COVID-19'un finansal etkileri finansal oranlar çerçevesinde incelenmediği için bu çalışma yöntem olarak diğerlerinden farklılaşmaktadır.

\section{ARAŞTIRMANIN KAPSAMI VE YÖNTEMİ}

Bu çalışmada, COVID-19' un Borsa İstanbul (BIST)' da işlem gören imalat sektörü firmalarına olan finansal etkisinin finansal oranlar kullanılarak istatistiksel olarak analiz edilmesi amaçlanmıştır. Bu çerçevede, "Kamu Aydınlatma Platformu (KAP)"nun yaptığı sektör sınıflandırması da dikkate alınarak imalat sektörü altındaki firmaların finansal oranların COVID-19 öncesi ve sonrası değerlerinin hesaplanıp dönemler arasında bir farklılık olup olmadığı istatistiksel analiz teknikleriyle ortaya çıkarılmaktadır.

Kamu Aydınlatma Platformu (KAP) tarafından yapılan sektör sınıflandırmasında imalat sektörü altında 175 firma listelenmektedir. Bu firmalardan 6'sının 2019 veya 2020 finansal tabloları yayınlanmamıștır. Geriye kalan firmalardan 2' sinin ise mali tablolarının istatistiki analize ${ }^{1}$ uygun olmadığı görülmüştür. Bunlara ek olarak "Diğer İmalat Sanayi”" başlığı altında ise 1 firma sınıflandırıldığı için bu firma da kapsam dışı bırakılmıştır. Bu nedenle bu araştırmanın veri setini BİST İmalat Sektöründe yer alan ve KAP tarafindan finansal tablo verileri açıklanan 166 firmanın COVID-19 öncesi (2019 ilk 6 aylık) ve sonrası (2020 ilk 6 aylık) finansal tablo verileri oluşturmaktadır. Araştırma kapsamına dahil edilen BİST İmalat sektörü firmalarının alt sektörlere göre dağılımı aşağıdaki şekildedir.

\footnotetext{
${ }^{1}$ Finansal oran hesaplamalarında kullanılan bazı değerler “ 0 ” olarak yer aldığı için oranları hesaplanamamıştır.
} 
Tablo 1. İmalat Sektöründeki Firma Bilgileri

\begin{tabular}{|l|c|c|}
\hline \multicolumn{1}{|c|}{ İmalat Alt Sektörleri } & Firma Sayısı & $\begin{array}{c}\text { Veri Setine } \\
\text { Dahil Edilen }\end{array}$ \\
\hline Gıda, İçecek ve Tütün & 27 & $\mathbf{2 4}$ \\
\hline Tekstil, Giyim Eşyası ve Deri & 23 & $\mathbf{2 2}$ \\
\hline Orman Ürünleri ve Mobilya & 5 & 5 \\
\hline Kâğıt ve Kâğı̈ Ürünleri, Basım ve Yayın & 13 & 13 \\
\hline Kimya İlaç Petrol Lastik ve Plastik Ürünler & 33 & $\mathbf{3 1}$ \\
\hline Taş ve Toprağa Dayalı & 22 & 22 \\
\hline Ana Metal Sanayii & 18 & $\mathbf{1 7}$ \\
\hline Metal Eşya Makine Elektrikli Cihazlar ve Ulaşım Araçları & 33 & 32 \\
\hline Diğer İmalat Sanayii & 1 & 0 \\
\hline \multicolumn{1}{|c|}{ Toplam } & $\mathbf{1 7 5}$ & $\mathbf{1 6 6}$ \\
\hline
\end{tabular}

Çalışmanın amacına yönelik olarak yukarıdaki tabloda yer alan firmaların ilgili finansal tablolarından elde edilen finansal oranlar şu şekildedir (Gümüş vd., 2017):

\section{- Likidite Oranları}

Genel olarak bu oranlar bir işletmenin elinde likit değer bulundurma ve borç ödeyebilme düzeyini göstermekte olup bu grupta hesaplanan oranlar şu şekildedir:

\begin{tabular}{|l|l|}
\hline \multicolumn{1}{|c|}{ Finansal Oran } & \multicolumn{1}{c|}{ Hesaplanma Şekli } \\
\hline Cari Oran (CA) & Dönen Varlıklar / Kısa Vadeli Yabancı Kay. \\
\hline Asit Test Oranı (ATO) & (Dönen V.- Stoklar) / KVYK \\
\hline Nakit Oran (NO) & (Hazır Değerler+ Ser. Menkul K.) / KVYK \\
\hline
\end{tabular}

\section{- Faaliyet Oranları}

Genel olarak bu oranlar, işletmeye ait olan satışlar ile varlık grupları arasındaki ilişkinin boyutunu göstermektedir. Aynı zamanda bu oranlar firmaların dönemdeki mal sirkülasyonu gibi faaliyetlerinin etkinliğine ilişkin bilgiler sunmaktadır. Bu grupta hesaplanan oranlar şu şekildedir: 


\begin{tabular}{|l|l|}
\hline \multicolumn{1}{|c|}{ Finansal Oran } & \multicolumn{1}{c|}{ Hesaplanma Şekli } \\
\hline Alacak Devir Hızı & Net Satışlar / Ticari Alacaklar \\
\hline Alacakların Ort. Tahsil Süresi & $180^{2} /$ Alacak Devir Hızı \\
\hline Stok Devir Hızı & Satı̧ların Maliyeti / Ortalama Stok Miktarı \\
\hline Stok Devir Süresi & 180 / Stok Devir Hızı \\
\hline Aktif Devir Hızı & Net Satışlar/ Aktif Toplamı \\
\hline
\end{tabular}

- Mali Yapı Oranları

Genel olarak bu oranlar, işletmenin finansmanı aşamasında yararlanılan yabancı kaynakların derecesini ölçmeyi sağlamakta olup bu grupta hesaplanan oranlar şu şekildedir:

\begin{tabular}{|l|l|}
\hline \multicolumn{1}{|c|}{ Finansal Oran } & \multicolumn{1}{c|}{ Hesaplama Şekli } \\
\hline Kaldıraç Oranı & Toplam Borç / Toplam Varlık \\
\hline KVYK Oranı & Kısa Vadeli Yabancı Kaynak / Pasif Toplamı) \\
\hline UVYK Oranı & Uzun Vadeli Yabancı Kaynak / Pasif Toplamı \\
\hline Özkaynak Oranı & Özkaynaklar/ Pasif Toplamı \\
\hline Yabancı Kaynak Oranı & Yabancı Kaynak / Özkaynak Oranı \\
\hline
\end{tabular}

\section{- Karlılık Oranları}

Genel olarak bu oranlar farklı açılardan işletmenin karlılık düzeyini ortaya koymakta olup bu grupta şu oranlar hesaplanmaktadır:

\begin{tabular}{|l|}
\hline \multicolumn{1}{|c|}{ Finansal Oran } \\
\hline Brüt Satış Karı / Net Satışlar \\
\hline Faaliyet Karı / Net Satışlar \\
\hline Dönem Karı / Net Satışlar \\
\hline Dönem Kârı / Aktif toplamı \\
\hline Dönem Kârı / Özkaynak Toplamı \\
\hline
\end{tabular}

Araştırma kapsamında BİST imalat sektörü firmalarından verilerine ulaşılan ve kapsama dahil edilen 166 firmanın mali tablolarından yukarıda belirtildiği şekilde finansal oranları ${ }^{3}$ hesaplanmıştır. Araştırmanın veri seti aşağıdaki sıra ile analize hazır hale getirilmiş ve analiz edilmiştir:

- İlk olarak, firmaların 2019 ve 2020 yılları ilk 6 aylık tarihli mali tablo verileri kullanılarak ilgili dönemlere ait finansal oranlar "Microsoft Excel" programı yardımıyla

\footnotetext{
${ }^{2}$ Veri setindeki mali tablolar 6 aylık (2019 ve 2020 ilk 6 ay) olduğu için süre olarak 180 gün baz alınmıştır.

${ }^{3} \mathrm{Bu}$ oranların kullanım amaçlarına ilişkin detaylı açıklamalar bulgular bölümünde gerekli görülen yerlerde yapılmıştır
} 
hesaplanmış, elde edilen finansal oranlar IBM SPSS 26 programına veri seti olarak kaydedilmiştir.

- İstatistiki bir çalışmada kullanılması gereken yöntemin belirlenmesi için ilk olarak verilerin normal dağılıp dağılmadığının incelenmesi gerekmektedir. Bu amaçla çalışmanın verilerinin normal dağılım gösterip göstermediğinin belirlenmesi için Kolmogorov Smirnov Z testi yapılmış ve çarpıklık-basıklık değerleri incelenmiştir. Yapılan Kolmogorov Smirnov Z testi sonucu ve elde edilen çarpıklık-basıklık değerlerine göre finansal oran değişkenlerine ait verilerin hiçbirinin normal dağılım göstermediği tespit edilmiştir. Farklılık analizlerinde verilerin normal dağılması halinde eşleştirilmiş $t$ testi uygulanması gerekirken, normal dağılmaması durumunda Wilcoxon İşaretli Sıralar Testi yapılmaktadır. Çalışmanın verileri normal dağılım göstermediği için çalışma verileri Wilcoxon İşaretli Sıralar Testi ile analiz edilmiştir.

- Son olarak, COVID-19'un BIST imalat sektörü alt gruplarındaki firmaları finansal açıdan ne düzeyde etkilediğini daha iyi anlayabilmek için finansal oranlar iki dönem arasındaki değişimin aktif büyüklüklerine göre tartılı aritmetik ortalamaları hem bir bütün olarak hem de sektörel bazda tablolar halinde hazırlanmıştır.

\section{BULGULAR}

Bir önceki bölümünde belirtildiği şekilde BIST imalat sektöründeki firmaların mali tablolarından elde edilen veri seti normal dağılım göstermediği için istatistiksel analiz yöntemi olarak "Wilcoxon İşaretli Sıralar Testi" kullanılmış olup ilk olarak bütün imalat sektörü bazında test uygulanmış, daha sonra ise alt sektörler için test tekrarlanmıştır.

BIST imalat sektörünün tamamı için yapılan "Wilcoxon İşaretli Sıralar Testi" sonuçlarına göre BIST imalat sektöründeki firmaların genel olarak COVID-19 öncesi ve sonrası dönemlerine ait finansal oranları arasındaki farklılıklara ilişkin elde edilen bulgular Tablo 2‘de görüldüğü şekildedir.

Tablo 2. Tüm İmalat Sektörünün COVID-19 Öncesi ve Sonrasındaki Dönemlere Göre Finansal Oranlarının Wilcoxon İşaretli Sıralar Testi Bulguları

\begin{tabular}{|c|l|l|c|c||}
\hline \multicolumn{2}{|c|}{ Finansal oranlar } & $\begin{array}{c}\text { Wilcoxon } \\
\text { İşaretli } \\
\text { Siralar } \\
\text { Testi }\end{array}$ & $\begin{array}{c}\text { Anlamlılı } \\
\text { (p değeri) }\end{array}$ \\
\hline \hline \multirow{3}{*}{$\begin{array}{c}\text { Likidite } \\
\text { Oranları }\end{array}$} & CA $^{\mathbf{4}}$ & Cari Oran & $-2,087$ & $\mathbf{0 , 0 3 7}$ \\
\cline { 2 - 5 } & ATO & Asit Test Oran & $-3,075$ & $\mathbf{0 , 0 0 2}$ \\
\cline { 2 - 5 } & NO & Nakit Oran & $-7,232$ & $\mathbf{0 , 0 0 0}$ \\
\hline \hline \multirow{4}{*}{\begin{tabular}{c} 
Faaliyet \\
\multirow{3}{*}{$\begin{array}{l}\text { Oranları } \\
\end{array}$}
\end{tabular}} & ADH & Alacak Devir Hızı & $-0,881$ & 0,378 \\
\cline { 2 - 5 } & AOTS & Alacakların Ortalama Devir Hızı & $-0,452$ & 0,651 \\
\cline { 2 - 5 } & SDH & Stok Devir Hızı & $-2,389$ & $\mathbf{0 , 0 1 7}$ \\
\cline { 2 - 5 } & SDS & Stok Devir Süresi & $-2,745$ & $\mathbf{0 , 0 0 6}$ \\
\cline { 2 - 5 } & AKDH & Aktif Devir Hızı & $-6,766$ & $\mathbf{0 , 0 0 0}$ \\
\hline
\end{tabular}

\footnotetext{
${ }^{4}$ Bundan sonraki tablo ve açıklamalarda genellikle oranların kısaltmaları kullanılmıştır.
} 


\begin{tabular}{||l|l|l|c|c||}
\hline \multirow{4}{*}{$\begin{array}{c}\text { Mali Yapı } \\
\text { Oranları }\end{array}$} & KO & Kaldıraç Oranı & $-1,698$ & $\mathbf{0 , 0 9 0}$ \\
\cline { 2 - 5 } & KVYKO & Kısa Vadeli Yabancı Kaynak Oranı & $-1,567$ & 0,117 \\
\cline { 2 - 5 } & UVYKO & Uzun Vadeli Yabancı Kaynak Oranı & $-4,167$ & $\mathbf{0 , 0 0 0}$ \\
\cline { 2 - 5 } & ÖO & Özkaynak Oranı & $-1,698$ & $\mathbf{0 , 0 9 0}$ \\
\cline { 2 - 5 } & YK/ÖO & Yabancı Kaynak/Özkaynak Oranı & $-1,698$ & $\mathbf{0 , 0 9 0}$ \\
\hline \hline \multirow{3}{*}{\begin{tabular}{c} 
Karlılık \\
\cline { 2 - 4 }
\end{tabular}} & BSK/NS & Brüt Satış Karı/ Net Satışlar & $-1,117$ & 0,264 \\
\cline { 2 - 5 } & FK/NS & Faaliyet Karı/ Net Satışlar & $-0,065$ & 0,948 \\
\cline { 2 - 5 } & DK/NS & Dönem Karı/ Net Satışlar & $-1,75$ & $\mathbf{0 , 0 8 0}$ \\
\cline { 2 - 5 } & DK/AT & Dönem Karı/ Aktif Toplamı & $-2,412$ & $\mathbf{0 , 0 1 6}$ \\
\cline { 2 - 5 } & DK/ÖT & Dönem Karı/ Özkaynak Toplamı & $-1,708$ & $\mathbf{0 , 0 8 8}$ \\
\hline
\end{tabular}

İstatiksel analizde $\mathrm{p}$ değerinin 0,05 'in altında olması durumunda istatistiksel olarak anlamlı fark olduğu kabul edilmektedir. Ayrıca, 0,1 ile 0,05 arasındaki bir değer ise "sınırlı anlamlılık" anlamına gelmektedir (Kul, 2014). Bu bilgilere göre Tablo 2'deki bilgileri şu şekilde yorumlayabiliriz:

- İmalat sektörünün bütünü için genel itibariyle likidite oranları açısından iki dönem arasında büyük ölçüde anlamlı farklılık vardır.

- Faaliyet oranlarından ise stok devir hızı, stok devir süresi ve aktif devir hızının farklılaştığı görülmektedir.

- Mali yapı oranlarından uzun vadeli yabancı kaynak oranı için anlamlı farklılık vardır. Ancak anlamlılık düzeyi 0,1 (sınırlı anlamlılık) olarak dikkate alındığında KVYKO hariç diğer Mali Yapı oranlarının hepsinde iki dönem arasında farklılık olduğu dikkati çekmektedir.

- Karlılık oranlarından ise "Dönem Karı/Aktif Toplamı" oranının anlamlı farklılık gösterdiği görülmektedir. Ancak mali yapı oranlarında olduğu şekilde anlamlılık düzeyi 0,1 (sınırlı anlamlılık) olarak dikkate alındığında farklılaşan karlılık oranı sayısının 3 olduğu görülmektedir.

Finansal oranlarda iki dönem arasında imalat sanayii alt sektörleri açısından anlamlı farklılıkların nasıl oluştuğunun anlaşılabilmesi amacıyla Wilcoxon İşaretli Sıralar Testi alt sektörler bazında tekrar yapılmış olup finansal oran gruplarına göre bulgular aşağıdaki Tablolarda (Tablo 3-7) verilmiştir. 
Tablo 3. Likidite Oranlarına İlişkin İmalat Sanayi Alt Sektörleri Wilcoxon İşaretli Siralar Testi Bulguları

\begin{tabular}{|c|c|c|c|c|}
\hline \multirow{2}{*}{ Alt Sektör } & & \multicolumn{3}{|c|}{ LİKİİTE ORANLARI } \\
\hline & & CA & ATO & NO \\
\hline \multirow{2}{*}{ Ana metal san. } & $\mathbf{W}$ & $-2,012$ & $-2,533$ & $-2,485$ \\
\hline & $\mathbf{P}$ & 0,044 & 0,011 & 0,013 \\
\hline \multirow{2}{*}{ Gıda, içecek } & $\mathbf{W}$ & $-0,200$ & $-0,229$ & $-1,886$ \\
\hline & $\mathbf{P}$ & 0,841 & 0,819 & 0,059 \\
\hline \multirow{2}{*}{ Kâğgıt } & $\mathbf{W}$ & $-0,804$ & $-0,594$ & $-1,782$ \\
\hline & $\mathbf{P}$ & 0,422 & 0,552 & $\mathbf{0 , 0 7 5}$ \\
\hline \multirow{2}{*}{ Kimya, ilaç } & $\mathbf{W}$ & $-0,666$ & $-1,666$ & $-3,508$ \\
\hline & $\mathbf{P}$ & 0,505 & 0,096 & 0,000 \\
\hline \multirow{2}{*}{ Metal eşya } & $\mathbf{W}$ & $-0,823$ & $-1,141$ & $-2,992$ \\
\hline & $\mathbf{P}$ & 0,411 & 0,254 & 0,003 \\
\hline \multirow{2}{*}{ Orman ürünleri } & $\mathbf{W}$ & $-0,135$ & $-0,135$ & $-1,753$ \\
\hline & $\mathbf{P}$ & 0,893 & 0,893 & 0,080 \\
\hline \multirow{2}{*}{$\begin{array}{l}\text { Taş ve toprağa dayalı } \\
\text { üretim }\end{array}$} & $\mathbf{W}$ & $-0,179$ & $-1,055$ & $-2,581$ \\
\hline & $\mathbf{P}$ & 0,858 & 0,291 & 0,010 \\
\hline \multirow{2}{*}{ Tekstil } & $\mathbf{W}$ & $-1,510$ & $-1,120$ & $-3,165$ \\
\hline & $\mathbf{P}$ & 0,131 & 0,263 & 0,002 \\
\hline
\end{tabular}

Tablo 3 incelendiğinde likidite oranlarının hepsi açısından "Ana Metal Sanayii” nin iki dönemi arasında anlamlı bir farklılık olduğu görülmektedir. Bunun haricinde nakit oranda (NO) bütün sektörlerde (5 sektörde 0,05 seviyesinde 3 sektörde 0,1 seviyesinde) anlamlı farklılık vardır. Oranların 0'a yakınlığına göre bakıldığında 0,000 ile kimya, ilaç sektöründe en anlamlı sonucun olduğu görülmektedir.

Tablo 4. Faaliyet Oranlarına İlişkin İmalat Sanayi Alt Sektörleri Wilcoxon İşaretli Siralar Testi Bulguları

\begin{tabular}{|l|c|r|r|r|r|r|}
\hline \multirow{2}{*}{ Alt Sektör } & & \multicolumn{5}{|c|}{ FAALIYET ORANLARI } \\
\cline { 3 - 7 } & & \multicolumn{1}{c|}{ ADH } & \multicolumn{1}{c|}{ AOTS } & \multicolumn{1}{c|}{ SDH } & \multicolumn{1}{c|}{ SDS } & \multicolumn{1}{c|}{ AKDH } \\
\hline \multirow{2}{*}{ Ana metal san. } & $\mathbf{W}$ & $-0,781$ & $-1,254$ & $-1,965$ & $-2,107$ & $-2,533$ \\
\cline { 2 - 7 } & $\mathbf{P}$ & 0,435 & 0,210 & $\mathbf{0 , 0 4 9}$ & $\mathbf{0 , 0 3 5}$ & $\mathbf{0 , 0 1 1}$ \\
\hline \multirow{2}{*}{ Gıda, içecek } & $\mathbf{W}$ & $-1,943$ & $-1,686$ & $-1,086$ & $-1,886$ & $-1,914$ \\
\hline \multirow{2}{*}{ Kâğıt } & $\mathbf{P}$ & $\mathbf{0 , 0 5 2}$ & $\mathbf{0 , 0 9 2}$ & 0,278 & $\mathbf{0 , 0 5 9}$ & $\mathbf{0 , 0 5 6}$ \\
\hline \multirow{2}{*}{ Kimya, ilaç } & $\mathbf{W}$ & $-0,734$ & $-1,433$ & $-0,804$ & $-0,175$ & $-2,132$ \\
\cline { 2 - 7 } & $\mathbf{P}$ & 0,463 & 0,152 & 0,422 & 0,861 & $\mathbf{0 , 0 3 3}$ \\
\hline \multirow{2}{*}{ Metal eşya } & $\mathbf{W}$ & $-2,175$ & $-1,744$ & $-1,058$ & $-0,176$ & $-2,704$ \\
\cline { 2 - 7 } & $\mathbf{P}$ & $\mathbf{0 , 0 3}$ & $\mathbf{0 , 0 8 1}$ & 0,290 & 0,860 & $\mathbf{0 , 0 0 7}$ \\
\hline & $\mathbf{W}$ & $-0,823$ & $-1,010$ & $-0,355$ & $-0,393$ & $-2,169$ \\
\cline { 2 - 7 } & $\mathbf{P}$ & 0,411 & 0,313 & 0,722 & 0,695 & $\mathbf{0 , 0 3 0}$ \\
\hline
\end{tabular}




\begin{tabular}{|l|c|r|r|r|r|r|}
\multirow{2}{*}{ Orman ürünleri } & $\mathbf{W}$ & $-0,674$ & $-1,214$ & $-1,483$ & $-1,483$ & $-2,023$ \\
\cline { 2 - 7 } & $\mathbf{P}$ & 0,500 & 0,225 & 0,138 & 0,138 & $\mathbf{0 , 0 4 3}$ \\
\hline \multirow{2}{*}{$\begin{array}{l}\text { Taş ve toprăga dayalı } \\
\text { üretim }\end{array}$} & $\mathbf{W}$ & $-0,438$ & $-0,081$ & $-1,834$ & $-0,828$ & $-1,023$ \\
\hline \multirow{2}{*}{ Tekstil } & $\mathbf{P}$ & 0,661 & 0,935 & $\mathbf{0 , 0 6 7}$ & 0,408 & 0,306 \\
\cline { 2 - 7 } & $\mathbf{W}$ & $-0,633$ & $-1,412$ & $-3,230$ & $-3,133$ & $-4,107$ \\
\cline { 2 - 7 } & $\mathbf{P}$ & 0,527 & 0,158 & $\mathbf{0 , 0 0 1}$ & $\mathbf{0 , 0 0 2}$ & $\mathbf{0 , 0 0 0}$ \\
\hline
\end{tabular}

Tablo 4'deki bilgiler incelendiğinde aktif devir hızı oranında "Taş ve Toprağa Dayalı Üretim” sektörü hariç diğer sektörlerde anlamlı bir farklılık olduğu görülmektedir. Bu sektörlerden en anlamı sonuç 0,000 ile "Tekstil" sektörüne aittir. Ayrıca stok devir hızı ve stok devir süresi açısından "Ana Metal" ve "Tekstil" sektörleri açısından anlamlı farklılık görülmektedir. Anlamlılık oranı 0,1 olarak dikkate alındığında "Gıda, İçecek" sektöründe 4 oranda sınırlı anlamlı farklılık görünmektedir. Buna ek olarak "Kimya, İlaç” Sektöründe alacakların devir hızı açısından anlamlı, alacakların ortalama tahsil süresi açısından sınırlı anlamlı farklılık vardır. “Taş ve Toprağa Dayalı Üretim” sektöründe ise sadece stok devir hızı açısından sınırlı anlamlılık görülmektedir.

İleriki bölümlerde görüleceği üzere “Ana Metal Sanayii” ile “Tekstil” sektörlerindeki firmaların hasılatlarında ciddi anlamda bir düşüş olduğu gözlemlenmiştir. Bu iki sektör açısından Tablo 4'deki stok devir ve aktif devir hızlarındaki anlamlı farklılıkların hasılatta meydana gelen düşüşten kaynaklandığı anlaşılmaktadır.

Tablo 5. Mali Yapı Oranlarına İlişkin İmalat Sanayi Alt Sektörleri Wilcoxon İşaretli Siralar Testi Bulguları

\begin{tabular}{|c|c|c|c|c|c|c|}
\hline \multirow{2}{*}{ Alt Sektör } & & \multicolumn{5}{|c|}{ MALİ YAPI ORANLARI } \\
\hline & & KO & KVYKO & UVYKO & ÖO & YK/ÖO \\
\hline \multirow{2}{*}{ Ana metal san. } & $\mathbf{W}$ & $-0,213$ & $-1,397$ & $-1,539$ & $-0,213$ & $-0,213$ \\
\hline & $\mathbf{P}$ & 0,831 & 0,163 & 0,124 & 0,831 & 0,831 \\
\hline \multirow{2}{*}{ Gıda, içecek } & $\mathbf{W}$ & $-1,086$ & $-0,971$ & $-0,686$ & $-1,086$ & $-1,086$ \\
\hline & $\mathbf{P}$ & 0,278 & 0,331 & 0,493 & 0,278 & 0,278 \\
\hline \multirow{2}{*}{ Kâğıt } & $\mathbf{W}$ & $-0,419$ & $-0,035$ & $-0,734$ & $-0,419$ & $-0,419$ \\
\hline & $\mathbf{P}$ & 0,675 & 0,972 & 0,463 & 0,675 & 0,675 \\
\hline \multirow{2}{*}{ Kimya, ilaç } & $\mathbf{W}$ & $-1,901$ & $-0,216$ & $-1,901$ & $-1,901$ & $-1,901$ \\
\hline & $\mathbf{P}$ & $\mathbf{0 , 0 5 7}$ & 0,829 & $\mathbf{0 , 0 5 7}$ & $\mathbf{0 , 0 5 7}$ & $\mathbf{0 , 0 5 7}$ \\
\hline \multirow{2}{*}{ Metal eşya } & $\mathbf{W}$ & $-1,440$ & $-1,683$ & $-3,908$ & $-1,440$ & $-1,440$ \\
\hline & $\mathbf{P}$ & 0,150 & 0,092 & 0,000 & 0,150 & 0,150 \\
\hline \multirow{2}{*}{ Orman ürünleri } & $\mathbf{W}$ & $-0,405$ & $-0,405$ & $-0,944$ & $-0,405$ & $-0,405$ \\
\hline & $\mathbf{P}$ & 0,686 & 0,686 & 0,345 & 0,686 & 0,686 \\
\hline \multirow{2}{*}{$\begin{array}{l}\text { Taş ve toprağa dayalı } \\
\text { üretim }\end{array}$} & $\mathbf{W}$ & $-1,217$ & $-0,308$ & $-2,938$ & $-1,217$ & $-1,217$ \\
\hline & $\mathbf{P}$ & 0,223 & 0,758 & 0,003 & 0,223 & 0,223 \\
\hline \multirow{2}{*}{ Tekstil } & $\mathbf{W}$ & $-0,211$ & $-0,114$ & $-0,276$ & $-0,211$ & $-0,211$ \\
\hline & $\mathbf{P}$ & 0,833 & 0,910 & 0,783 & 0,833 & 0,833 \\
\hline
\end{tabular}


Tablo 5'deki bilgiler incelendiğinde uzun vadeli yabancı kaynaklar oranının "Metal Eşya" ve "Taş ve Toprağa Dayalı Üretim" sektörleri açısından anlamlı bir farklılık görülmektedir. $\mathrm{Bu}$ anlamlı farklılı̆̆ın daha iyi anlaşılması için ileriki tablolarda oranların ortalama değişimleri incelenmiştir. Buna ek olarak tabloda görüldüğü üzere "Kimya, İlaç" sektöründe kısa vadeli yabancı kaynaklar oranı hariç diğer oranlarda anlamlı bir farklılık görülmektedir. Bunlar haricinde diğer sektörlerde hem 0,05 düzeyinde hem de 0,1 düzeyinde anlamlı bir farklılık olmadığı görülmektedir.

Tablo 6. Karlılık Oranlarına İlişkin İmalat Sanayi Alt Sektörleri Wilcoxon İşaretli Siralar Testi Bulguları

\begin{tabular}{|c|c|c|c|c|c|c|}
\hline \multirow{2}{*}{ Alt Sektör } & & \multicolumn{5}{|c|}{ KARLILIK ORANLARI } \\
\hline & & BSK/NS & FK/NS & DK/NS & DK/AT & DK/ÖT \\
\hline \multirow{2}{*}{ Ana metal san. } & $\mathrm{W}$ & $-0,852$ & $-0,734$ & $-1,870$ & $-1,965$ & $-2,391$ \\
\hline & $\mathrm{P}$ & 0,394 & 0,463 & 0,062 & 0,049 & 0,017 \\
\hline \multirow{2}{*}{ Gıda, içecek } & $\mathrm{W}$ & $-0,271$ & $-0,114$ & $-0,486$ & $-0,143$ & $-0,286$ \\
\hline & $\mathrm{P}$ & 0,786 & 0,909 & 0,627 & 0,886 & 0,775 \\
\hline \multirow{2}{*}{ Kimya, ilaç } & $\mathbf{W}$ & $-0,901$ & $-1,127$ & $-0,510$ & $-0,549$ & $-0,235$ \\
\hline & $\mathbf{P}$ & 0,367 & 0,260 & 0,610 & 0,583 & 0,814 \\
\hline \multirow{2}{*}{ Metal eşya } & $\mathbf{W}$ & $-1,309$ & $-0,654$ & $-0,243$ & $-0,980$ & $-1,515$ \\
\hline & $\mathbf{P}$ & 0,191 & 0,513 & 0,808 & 0,327 & 0,130 \\
\hline \multirow{2}{*}{ Orman ürünleri } & $\mathbf{W}$ & $-0,405$ & $-0,135$ & $-0,674$ & $-0,405$ & $-0,405$ \\
\hline & $\mathbf{P}$ & 0,686 & 0,893 & 0,500 & 0,686 & 0,686 \\
\hline \multirow{2}{*}{ Taş ve toprağa dayalı } & $\mathbf{W}$ & $-0,503$ & $-0,211$ & $-0,795$ & $-0,958$ & $-1,185$ \\
\hline & $\mathbf{P}$ & 0,615 & 0,833 & 0,426 & 0,338 & 0,236 \\
\hline \multirow{2}{*}{ Tekstil } & $\mathbf{W}$ & $-0,601$ & $-1,380$ & $-1,153$ & $-2,045$ & $-1,217$ \\
\hline & $\mathbf{P}$ & 0,548 & 0,168 & 0,249 & 0,041 & 0,223 \\
\hline
\end{tabular}

Tablo 6'daki bilgilere bakıldığında açık bir şekilde karlılık oranları açısından sadece Ana Metal Sanayii' nde iki oran (DK/AT, DK/ÖT) ve Tekstil sektöründe ise 1 oranda (DK/AT) anlamlı farklılık görünmektedir. KO doğrudan hasılat ile ilişkili olduğu için bu konudaki açıklamalar ileriki bölümlerde yapılmıştır. 
Tablo 7. İmalat Alt Sektörlerine ait finansal oranların Wilcoxon İşaretli Sıralar Testi Bulguları Özeti (Anlamlılık Düzeyi=0,05)

\begin{tabular}{|c|c|c|c|c|c|}
\hline İmalat Alt Sektörü & $\begin{array}{c}\text { Anlamlı } \\
\text { Farklılık Olan } \\
\text { Oran Sayısı }\end{array}$ & $\begin{array}{l}\text { Likidite } \\
\text { Oranları }\end{array}$ & $\begin{array}{l}\text { Faaliyet } \\
\text { Oranları }\end{array}$ & $\begin{array}{l}\text { Mali Yapı } \\
\text { Oranları }\end{array}$ & $\begin{array}{l}\text { Karlılık } \\
\text { Oranları }\end{array}$ \\
\hline Anametal Sanayi & 8 & $\begin{array}{l}\text { CA, ATO } \\
\text { NO }\end{array}$ & $\begin{array}{c}\text { SDH, SDS } \\
\text { AKDH }\end{array}$ & - & $\begin{array}{l}\mathrm{DK} / \mathrm{AT} \\
\mathrm{DK} / \mathrm{ÖT}\end{array}$ \\
\hline Gıda, İçecek ve Tütün & $\mathbf{0}$ & - & - & - & - \\
\hline Kâğıt ve K. Ürünleri, Basım & 1 & - & AKDH & - & - \\
\hline Kimya, İlaç, Petrol, Lastik.. & 3 & NO & $\mathrm{ADH}, \mathrm{AKDH}$ & - & - \\
\hline $\begin{array}{l}\text { Metal Eşya, Makine, Elektrikli } \\
\text { Cihaz }\end{array}$ & 3 & NO & AKDH & UVYKO & - \\
\hline Orman Ürünleri ve Mobilya & 1 & - & AKDH & - & - \\
\hline Taş ve Toprağa Dayalı & 2 & NO & - & UVYKO & - \\
\hline Tekstil, Giyim Eşyası ve Deri & 5 & $\begin{array}{l}\text { NO } \\
\text { NO }\end{array}$ & $\begin{array}{c}\text { SDH, SDS } \\
\text { AKDH }\end{array}$ & - & DK/AT \\
\hline
\end{tabular}

Wilcoxon İşaretli Sıralar Testi' nin sonuçlarına ilişkin özet bilgilerin bulunduğu Tablo 7'deki bilgilere bakıldığında en çok faaliyet oranları (11 Oran) ve likidite oranları (8 oran) açısından anlamlı farklılık olduğu dikkati çekmektedir. Sektörler bazında da en çok Ana Metal (8 oran) ve Tekstil (5 oran) sektörlerinde anlamlı farklılık görülmektedir. Wilcoxon İşaretli Sıralar Testi sonuçları bize genel olarak iki ölçüm arasında anlamlı bir farklılık olup olmadığını göstermektedir. Farklılıkların yönünün ve hangi firmalardan kaynaklandığının anlaşılabilmesi için finansal oranların ortalamalarında ve firmaların hasılatlarında meydana gelen değişimin bilinmesi gerekmektedir. Bu nedenle aşağıdaki tablolarda gerekli bilgilere yer verilmiştir.

Tablo 8. Finansal Oranların 2019-2020 İlk 6 Aylık Dönemler Arasındaki Ortalama Değişim Yüzdesi

\begin{tabular}{|c|c|c|c|c|c|c|c|c|c|c|}
\hline \multirow{2}{*}{\multicolumn{2}{|c|}{ Finansal Oranlar }} & \multicolumn{9}{|c|}{ ORANLARDAKİ ORTALAMA DEĞİşiM (\%) } \\
\hline & & \multirow{2}{*}{ 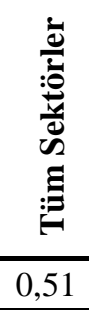 } & \multirow{2}{*}{ 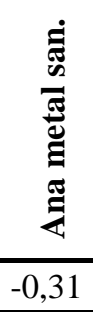 } & \multirow{2}{*}{ 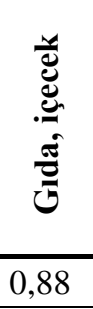 } & \multirow{2}{*}{ 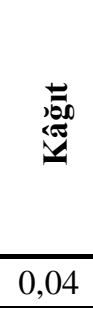 } & \multirow{2}{*}{ 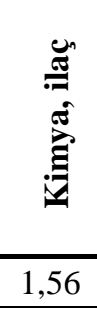 } & \multirow{2}{*}{ 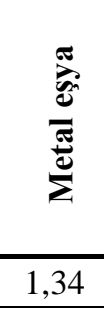 } & \multirow{2}{*}{ 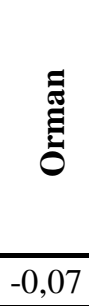 } & \multirow{2}{*}{ 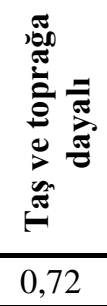 } & \multirow{2}{*}{ 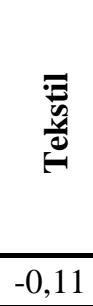 } \\
\hline \multirow{3}{*}{$\begin{array}{l}\text { Likidite } \\
\text { Oranları }\end{array}$} & $\mathbf{C A}$ & & & & & & & & & \\
\hline & ATO & 1,20 & 0,19 & 0,54 & 0,47 & 3,09 & 2,41 & $-0,10$ & 2,91 & 0,12 \\
\hline & NO & 29,9 & 72,37 & 16,91 & 13,57 & 11,95 & 54,09 & 2,64 & 53,84 & 13,47 \\
\hline \multirow{3}{*}{$\begin{array}{l}\text { Faaliyet } \\
\text { Oranları }\end{array}$} & $\mathrm{ADH}$ & 0,71 & $-0,13$ & 1,25 & $-0,22$ & 2,40 & 0,33 & 0,19 & 1,55 & 0,30 \\
\hline & AOTS & 0,93 & 2,87 & $-0,34$ & 0,55 & 3,46 & 0,96 & $-0,12$ & $-0,70$ & 0,73 \\
\hline & SDH & 0,66 & $-1,99$ & $-0,83$ & 0,44 & 0,34 & 1,93 & $-0,29$ & 9,10 & $-3,40$ \\
\hline
\end{tabular}




\begin{tabular}{|l|l|c|c|c|c|c|c|c|c|c|} 
& SDS & 1,03 & 3,51 & 1,22 & $-0,09$ & 0,35 & 0,56 & 0,39 & $-3,66$ & 5,95 \\
\cline { 2 - 10 } & AKDH & $\mathbf{- 1 , 2}$ & $\mathbf{- 3 , 4 1}$ & $\mathbf{- 0 , 5 7}$ & $\mathbf{- 0 , 3 4}$ & $\mathbf{- 0 , 6 6}$ & $\mathbf{- 0 , 9 4}$ & $\mathbf{- 0 , 1 8}$ & $\mathbf{0 , 7 3}$ & $\mathbf{- 4 , 2 3}$ \\
\hline \multirow{4}{*}{$\begin{array}{c}\text { Mali Yapı } \\
\text { Oranları }\end{array}$} & KO & 0,93 & 1,79 & $-0,25$ & 0,01 & 0,09 & 0,36 & 0,02 & 4,77 & 0,56 \\
\cline { 2 - 10 } & KVYKO & 1,38 & 3,25 & $-0,3$ & $-0,01$ & 1,95 & $-0,88$ & 0,03 & 5,71 & 1,28 \\
\cline { 2 - 10 } & UVYKO & $\mathbf{7 , 2 6}$ & $\mathbf{1 2 , 6 6}$ & $\mathbf{4 , 7 9}$ & $\mathbf{0 , 5 1}$ & $\mathbf{2 1 , 4 3}$ & $\mathbf{1 1 , 4 6}$ & $\mathbf{0 , 0 8}$ & $\mathbf{6 , 7 1}$ & $\mathbf{0 , 5 9}$ \\
\cline { 2 - 10 } & ÖO & $\mathbf{- 0 , 9 4}$ & $-6,27$ & 0,51 & $-0,16$ & 0,51 & 0,48 & $-0,83$ & $-1,28$ & $-0,49$ \\
\cline { 2 - 10 } & YK/ÖO & 0,93 & 1,79 & $-0,25$ & 0,01 & 0,09 & 0,36 & 0,02 & 4,77 & 0,56 \\
\hline \multirow{4}{*}{$\begin{array}{c}\text { Karlılık } \\
\text { Oranları }\end{array}$} & BSK/NS & 0,58 & $\mathbf{- 1 2 , 1 1}$ & 1,35 & 5,05 & 0,64 & 1,65 & 0,06 & 8,08 & $-0,14$ \\
\cline { 2 - 10 } & FK/NS & $\mathbf{- 4 , 7 5}$ & $\mathbf{- 2 8 , 8}$ & $-1,92$ & 0,84 & 2,13 & $-4,45$ & 0,42 & $-4,16$ & $-2,03$ \\
\cline { 2 - 10 } & DK/NS & 28,23 & $\mathbf{- 2 8 , 4}$ & $-2,9$ & $-4,32$ & $\mathbf{2 3 5 , 5 9}$ & 13,64 & 0,70 & 7,52 & 4,00 \\
\cline { 2 - 10 } & DK/AT & 33,77 & $\mathbf{- 2 5 , 9 1}$ & $-1,02$ & $-3,86$ & $\mathbf{2 7 6 , 5 7}$ & 16,65 & 0,44 & 8,55 & $-1,28$ \\
\cline { 2 - 10 } & DK/ÖT & 46,98 & $\mathbf{- 4 9 , 6 4}$ & $\mathbf{1 1 9 , 3 1}$ & $-5,06$ & $\mathbf{2 7 5 , 4 2}$ & 11,68 & $-1,23$ & 12,62 & 12,73 \\
\hline
\end{tabular}

Tablo 8' deki bilgiler incelendiğinde ilk olarak finansal oranlardan NO ve UVYKO' da pozitif yönlü olarak bir değişi dikkati çekmektedir. Bunun nedeninin anlaşılması amacıyla yapılan incelemede şu bilgilere ulaşılmıştır:

Salgının Türkiye'de etkisini göstermeye başladığı günlerde T.C. Hazine ve Maliye Bakanlığı tarafından COVID-19 Ekonomik İstikrar Kalkanı Paketi yayınlanmıştır (Anadolu Ajans1, 2020). Bu paket içinde özellikle salgının firmalar üzerindeki finansal etkilerini hafifletmeye yönelik tedbirler dikkat çekmektedir. Bunların en önemlilerinden biri Kamu Bankaları tarafından firmalara 6 ay geri ödemesiz 36 ay vadeli kredi desteği sağlanmasıdır (İş ve İnşaat Makineleri Kümelenmesi, 2020). Bu bilgiler ile nakit oran ve uzun vadeli yabanci kaynak oranlarının pozitif değişimi düşünüldüğünde, firmaların büyük bir bölümünün bu kredi desteğinden faydalandığı anlaşılabilir. Wilcoxon İşaretli Sıralar Testi sonuçlarına baktığımızda ise UVYKO' da “Metal Eşya, Makine, Elektrikli Cihaz” ile "Taş ve Toprağa Dayalı" sektörlerinde anlamlı bir değişim görülmektedir. Ortalama değişimler tablosu ile Wilcoxon İşaretli Sıralar Testi sonuçlarını birlikte ele aldığımızda ise bütün sektörlerdeki firmalar tarafından uzun vadeli kredi kullanımına yönelme olmasına rağmen bu iki sektördeki firmaların geneli tarafından kredi kullanıldığı düşünülebilir. Tablo 8'e bakıldığında UVYKO' daki artışın yanında ÖO’ da sektörlerin çoğunluğunda negatif yönlü bir değişim olduğu görülmektedir. $\mathrm{Bu}$ da alınan uzun vadeli kredilerin firmaların ÖO’ yu düşürdüğü şeklinde yorumlanabilir. Ayrıca NO’ daki değişime bakılırsa Metal Eşya $(\% 54,09)$ ile Taş ve Toprağa Dayalı $(\%$ 53,84) sektörlerindeki ciddi artışın kredi kullanımından kaynaklanmış olabileceği söylenebilir.

Bunların dışında "Taş ve Toprağa Dayalı Üretim” sektörü hariç diğer sektörlerin tamamında $\mathrm{ADH}$ açısından negatif değişim görülmektedir. Ayrıca FK/NS sektörlerin büyük bölümünde negatif yönlü bir değişim görülmektedir. Ayrıca karlılık oranları açısından Ana Metal Sanayi' inde negatif yönlü ciddi bir değişim görünmesinin aksine 'Kimya, İlaç, Petrol, Lastik” sektörü açısından pozitif yönlü istisnai bir artış dikkat çekmektedir. Bunların yanında Gıda sektöründe genel olarak olumsuz bir tablo görülürken DK/ÖT oranında bir artış göze çarpmaktadır. Tespit edilen durumları daha iyi anlaşılabilmesi için sektörlerde faaliyet gösteren firmaların 6 aylık hasılat değişiminin bilinmesi gerekmektedir. Bu nedenle aşağıdaki tabloda hasılat değişimlerine yer verilmiştir. 
Tablo 9. İmalat Sanayii Alt Sektörlerinin Hasılatlarının Dönemlere Göre Değişimi

\begin{tabular}{|c|c|c|c|}
\hline İmalat Alt Sektörleri & $\begin{array}{c}\text { Hasılatı Düşen } \\
\text { Firma }\end{array}$ & $\begin{array}{c}\text { Hasılatı } \\
\text { Artan Firma }\end{array}$ & Toplam \\
\hline Ana Metal Sanayii & 13 & 4 & 17 \\
\hline Tekstil, Giyim Eşyası ve Deri & 17 & 5 & 22 \\
\hline Kâğıt ve Kâğgt Ürünleri, Basım ve Yayın & 7 & 6 & 13 \\
\hline Kimya İlaç Petrol Lastik ve Plastik Ürünler & 10 & 21 & 31 \\
\hline Gıda, İçecek ve Tütün & 5 & 19 & 24 \\
\hline Metal Eşya Makine Elektrikli Cihazlar & 14 & 18 & 32 \\
\hline Taş ve Toprağa Dayalı & 7 & 15 & 22 \\
\hline Orman Ürünleri ve Mobilya & 2 & 3 & 5 \\
\hline Toplam & 75 & 91 & 166 \\
\hline
\end{tabular}

Tablo 9'deki bilgiler incelendiğinde COVID-19'un etkisini gösterdiği dönemde 3 sektörde firmaların çoğunluğunda hasılat düşüşü gözlenirken diğer sektörlerde hasılatlarda artış meydana gelmiştir. Bu dönemde en çok hasılat düşüklüğü yaşayan firma sayısı Tekstil, Giyim Eşyası ve Deri sektöründe (17 firma) iken en çok hasılat artışı yaşayan firma Gıda, İçecek ve Tütün (19 firma) sektöründe görülmektedir. Aşağıdaki tablolarda sektörlerde hasılatı en çok düşen ve en çok artan firmalara yer verilmiştir

Tablo 10. Ana Metal Sektöründeki Firmalardan Hasılatı En Çok Düşen ve En Çok Artan Firmalar

\begin{tabular}{|c|c|c|c|c|}
\hline \multirow[b]{2}{*}{ Kodu } & \multirow[b]{2}{*}{ Şirket Adı } & \multicolumn{2}{|c|}{ Hasılat (ilk 6 Ay) } & \multirow{2}{*}{$\begin{array}{c}\text { Değişim } \\
\text { (\%) }\end{array}$} \\
\hline & & 2020 & 2019 & \\
\hline ERBOS & Erbosan Erciyas Boru & 216.217.154 & 323.540 .885 & $-33,17$ \\
\hline TUCLK & Tuğçelik Alüminyum ve Metal M. & 61.176 .058 & 86.295 .024 & $-29,11$ \\
\hline DMSAS & Demisaş Döküm Emaye M. & 144.525 .466 & 201.568 .965 & $-28,30$ \\
\hline BURVA & Burçelik Vana & 3.523.352 & 4.646 .450 & $-24,17$ \\
\hline BRSAN & Borusan Mannesmann Boru & 1.830.106.704 & 2.331.151.532 & $-21,49$ \\
\hline CUSAN & Çuhadaroğlu Metal & 174.348.843 & 163.096 .081 & 6,90 \\
\hline CEMAS & Çemaş Döküm & 96.737 .164 & 77.331 .140 & 25,09 \\
\hline ERGLİ & Ereğli Demir ve Çelik & 257.007 .752 & 195.478 .504 & 31,48 \\
\hline OZBAL & Özbal Çelik Boru & 61.813 .599 & 8.021 .766 & 670,57 \\
\hline
\end{tabular}

Tablo 9'da görüldüğü üzere Ana Metal sektöründe faaliyet gösteren firmalardan 13'ünün hasılatı düşerken sadece 4'ünün hasılatında artış olmuştur. Bu da sektörün COVID19'un ortaya çıkardığı krizden genel olarak olumsuz etkilendiğini göstermektedir. Tablo 10'a bakıldığında bu dönemde en çok hasılatı düşen firmanın Erbosan Erciyas Boru olduğu görülmektedir. Hasılat artışı ile yaşayan firmalar ile ilgili inceleme yapıldığında hasılat artışının COVID-19 döneminin özellikleri ile ilgili olmadığı, firmaların kendi özel 
durumlarından kaynaklanmış olduğu düşünülmektedir. İstisnai bir artış görünen Özbal Çelik Boru Firması ile ilgili yapılan incelemede 2018 (ilk altı ay) mali tablolarında 60.822.344 TL hasılat raporladığı görülmektedir. Dolayısıyla 2019 (ilk altı ay) raporlanan hasılatın firmanın genel durumunu yansıtmadığı ve 2020'de görülen kâr artışının normalleşme durumu olduğu anlaşılmıştır.

Tablo 11. Tekstil, Giyim Eşyası ve Deri Sektöründeki Firmalardan Hasılatı En Çok Düşen ve En Çok Artan Firmalar

\begin{tabular}{|c|c|c|c|c|}
\hline \multirow[b]{2}{*}{ Kodu } & \multirow[b]{2}{*}{ Şirket Adı } & \multicolumn{2}{|c|}{ Hasilat (ilk 6 Ay) } & \multirow{2}{*}{$\begin{array}{c}\text { Değişim } \\
(\%)\end{array}$} \\
\hline & & 2020 & 2019 & \\
\hline BLCYT & Bilici Yatırım & 54.916 .657 & 105.790 .382 & $-48,09$ \\
\hline DESA & Desa Deri & 99.834 .738 & 190.492 .386 & $-47,59$ \\
\hline BRMEN & Birlik Mensucat & 968.965 & 1.805 .384 & $-46,33$ \\
\hline DAGI & Daği Giyim & 41.288 .390 & 67.603 .197 & $-38,93$ \\
\hline ARSAN & Arsan Tekstil & 97.190 .503 & 147.507 .810 & $-34,11$ \\
\hline DERIM & Derimod Konfeksiyon & 115.238.372 & 112.427 .449 & 2,50 \\
\hline SNPAM & Sönmez Pamuklu & 29.910.971 & 28.638.787 & 4,44 \\
\hline YATAS & Yataş Yatak ve Yorgan & 605.673 .841 & 556.080 .896 & 8,92 \\
\hline MNDRS & Menderes Tekstil & 622.918 .851 & 561.781 .628 & 10,88 \\
\hline HATEK & Hatay Tekstil & 89.151 .883 & 78.429 .310 & 13,67 \\
\hline
\end{tabular}

Tablo 9'daki bilgiler incelendiğinde Tekstil, Giyim Eşyası ve Deri sektöründeki firmalardan 17'sinin hasılatında düşme meydana gelirken sadece 5 firmanın hasılatı yükselmiştir. Ana Metal sektöründe olduğu gibi COVID-19 döneminde Tekstil, Giyim Eşyası ve Deri sektöründeki firmalarının büyük çoğunluğunun hasılatı olumsuz etkilenmiştir. $\mathrm{Bu}$ dönemde özellikle erkek ve kadın giyim sektörü satışları olumsuz etkilenmiştir (Euronews, 2020). Bu duruma Ramazan Bayramı'nda yapılan sokağa çıkma kısıtlamasın da etkisinin olduğu söylenebilir.

Tablo 11'de görüldüğü üzere en çok hasılat düşüklügü Bilici Yatırım'da meydana gelmiştir. Yapılan incelemede bu firmanın da tekstil sektörü için iplik üreten bir firma olduğu görülmüştür. Tekstil, Giyim Eşyası ve Deri sektöründeki firmalardan hasılatları yükselenler ile ilgili yapılan incelemede COVID-19 dönemi ile ilgili bir bilgiye rastlanmamıştır. Ancak en çok hasılat artışı olan Hatay Tekstil'in havlu üretimi yaptığı tespit edilmiştir. Bu bakış açısı ile COVID-19 döneminde havlu, koruyucu kıyafet gibi kişiye özel temizlik ve giyim ürünlerinin talebindeki artışın bu çerçevede üretim yapan firmaların karlılıklarını olumlu yönde etkilediği düşünülebilir. 
Tablo 12: Kâğıt ve Kâğıt Ürünleri, Basım ve Yayın Sektöründeki Firmalardan Hasılatı En Çok Düşen ve En Çok Artanlar

\begin{tabular}{|l|l|r|r|r|}
\hline \multicolumn{2}{|c|}{ Şirket Adı } & \multicolumn{2}{c|}{ Hasılat (ilk 6 Ay) } & \multicolumn{1}{c|}{ Değişim } \\
Kodu & \multicolumn{1}{|c|}{$\mathbf{2 0 2 0}$} & \multicolumn{1}{c|}{$\mathbf{2 0 1 9}$} & \multicolumn{1}{c|}{$\mathbf{( 0 )}$} \\
\hline VKING & Viking Kâğıt ve Selüloz & 129.703 .203 & 235.110 .122 & $\mathbf{- 4 4 , 8 3}$ \\
\hline DOBUR & Doğan Burda Dergi Yayın. & 26.517 .818 & 44.349 .131 & $\mathbf{- 4 0 , 2 1}$ \\
\hline PRZMA & Prizma Pres Matbaacılık & 2.533 .584 & 3.244 .679 & $\mathbf{- 2 1 , 9 2}$ \\
\hline HURGZ & Hürriyet Gazetecilik & 145.304 .482 & 185.762 .167 & $\mathbf{- 2 1 , 7 8}$ \\
\hline IHGZT & İhlas Gazetecilik & 63.456 .033 & 71.308 .004 & $\mathbf{- 1 1 , 0 1}$ \\
\hline OLMIP & Olmuksan Ambalaj & 548.267 .550 & 522.269 .301 & $\mathbf{4 , 9 8}$ \\
\hline DURDO & D. Doğan Basım ve Ambalaj & 115.990 .588 & 106.462 .398 & $\mathbf{8 , 9 5}$ \\
\hline SAMAT & Saray Matbaacılık & 39.417 .625 & 32.541 .055 & $\mathbf{2 1 , 1 3}$ \\
\hline KARTN & Kartonsan Karton & 608.193 .347 & 388.185 .992 & $\mathbf{5 6 , 6 8}$ \\
\hline BAKAB & Bak Ambalaj & 286.878 .912 & 115.299 .081 & $\mathbf{1 4 8 , 8 1}$ \\
\hline
\end{tabular}

Tablo 12'deki bilgiler incelendiğinde genel itibariyle kâğıt ve kâğıt ürünleri üreten firmalar ile "Basım-Yayın” sektöründe hasılat düşüklüğü meydana geldiği görülmektedir. Bunun sebeplerinden birinin COVID-19 tedbirleri kapsamında yüz yüze eğitimden uzaktan eğitime geçilmesi ile kâğıt ürünleri ile basılı materyallere olan talebin azalması olduğu düşünülebilir. Sektörde hasılatı artan firmaların geneline baktığımızda ise Saray Matbaacılık hariç ambalaj ürünleri üreten firmalar olduğu görülmektedir. Özellikle bu süreçte Bak Ambalaj Firması' nın ciddi hasılat artışı sağladığı dikkati çekmektedir.

Tablo 13. Kimya, İlaç Petrol Lastik ve Plastik Ürünler Sektöründeki Firmalardan Hasılatı En Çok Düşen ve En Çok Artanlar

\begin{tabular}{|c|c|c|c|c|}
\hline \multirow[b]{2}{*}{ Kodu } & \multirow[b]{2}{*}{ Şirket Adı } & \multicolumn{2}{|c|}{ Hasslat (İlk 6 Ay) } & \multirow{2}{*}{$\begin{array}{c}\text { Değişisim } \\
\text { (\%) }\end{array}$} \\
\hline & & 2020 & 2019 & \\
\hline BRMEN & Birlik Mensucat & 968.965 & 1.805 .384 & $-46,33$ \\
\hline TUPRS & TÜPRAŞ-Türkiye Petrolleri & 26.219 .118 & 44.660 .839 & $-41,29$ \\
\hline GOODY & Goodyear Lastikleri & 1.164 .572 .041 & 1.436 .637 .120 & $-18,94$ \\
\hline AYGAZ & Aygaz & 4.150 .354 & 5.096 .292 & $-18,56$ \\
\hline PETKM & PETKİM Petrokimya Holding & 5.007 .961 & 5.940 .555 & $-15,70$ \\
\hline SEKUR & Sekuro Plastik Ambalaj & 94.588 .296 & 68.778 .288 & 37,53 \\
\hline SASA & Sasa Polyester San. & 1.863 .186 & 1.260 .775 & 47,78 \\
\hline SEYKM & Seyitler Kimya & 21.378 .169 & 14.334 .549 & 49,14 \\
\hline MEGAP & Mega Polietilen Köpük & 132.572 .244 & 55.093 .508 & 140,6 \\
\hline RTALB & RTA Lab. Biyolojik Ürünler İlaç & 77.299 .889 & 9.098 .447 & 749,5 \\
\hline
\end{tabular}

Tablo 9'daki bilgilere bakıldığında 10 firmanın hasılatında düşüş yaşanmasının aksine 21 firmanın hasılatında artış meydana gelmiştir. Tablo 13'de hasılatı en çok düşen firmalara 
baktığımızda petrol ve petrole dayalı ürünler üreten firmaların süreçten olumsuz yönde etkilendiği dikkati çekmektedir.

Tablo 13'de hasılatında en çok artış meydana gelen firmalara baktığımızda iki durum dikkati çekmektedir. Bunlardan ilki RTA Laboratuvarları Biyolojik Ürünler İlaç Firması' nın hasılatındaki çok yüksek artıştır. Bu konuda yapılan incelemede RTA Laboratuvarları Biyolojik Ürünler İlaç Firması'nın 13.03.2020 tarihinde Korona virüs tanısı için gerekli (SWAB+ İzolasyon Kiti+ CORONA VİRUS Tanı Kiti) kit üretimi ve dağıtımı için tüm parametrelerini tamamlamış olduğunu duyurduğu tespit edilmiştir (Uzmanpara, 2020). Bu süreçte COVID-19 tanı kitlerinin üretimini ve satışını yapan firma süreçten ciddi anlamda olumlu yönden etkilenmiştir.

Hasılatı artan diğer firmalara baktığımızda ise Kâğıt Sektöründe olduğu gibi birçoğunun ambalaj üreten firmalar olduğudur. Ayrıca hasılatı artan diğer bir firma olan Seyitler Kimya, maske ve hijyen ürünleri üretmektedir. Benzer şekilde Sasa Polyester de üretimini hijyen ve ambalaj malzemesine yönlendirerek hasılat artışı sağlamıştır (SASA, 2020).

Tablo 14. Gıda, İçecek ve Tütün Sektöründeki Firmalardan Hasılatı En Çok Düşen ve En Çok Artanlar

\begin{tabular}{|c|c|c|c|c|}
\hline \multirow[b]{2}{*}{ Kodu } & \multirow[b]{2}{*}{ Şirket Adı } & \multicolumn{2}{|c|}{ Hasılat (İlk 6 Ay) } & \multirow{2}{*}{$\begin{array}{c}\text { Değişim } \\
\text { (\%) }\end{array}$} \\
\hline & & 2020 & 2019 & \\
\hline EKIZ & Ekiz Kimya Sanayi & 7.664 .584 & 19.590 .237 & $-60,88$ \\
\hline SELGD & Selçuk Gıda Endüstri & 2.597 .030 & 5.784 .805 & $-55,11$ \\
\hline ERSU & Ersu Meyve ve Gida & 2.385 .416 & 4.647 .317 & $-48,67$ \\
\hline PINSU & Pınar Su ve İçecek & 97.665 .721 & 113.846 .598 & $-14,21$ \\
\hline BANVT & Bandırma Vitaminli Yem & 1.763 .336 .797 & 1.791.177.842 & $-1,55$ \\
\hline PENGD & Penguen Gida & 82.811 .345 & 60.151 .567 & 37,67 \\
\hline KNFRT & Konfrut G1da Sanayi & 151.270 .242 & 109.175 .819 & 38,56 \\
\hline ULUUN & Ulusoy Un Sanayi & 2.165 .124 .022 & 1.510.796.915 & 43,31 \\
\hline OYLUM & Oylum Sınai Yatırımları & 37.079 .243 & 25.260 .165 & 46,79 \\
\hline DARDL & Dardanel Önantaş Gıda & 462.297 .506 & 235.786 .155 & 96,07 \\
\hline
\end{tabular}

Tablo 9'a bakıldığında “Gıda, İçecek ve Tütün” sektörü firmalarından sadece 5’nin hasılatında düşme meydana gelirken 19'nda hasılat artışı olduğu görülmektedir. Hasılat artışının yüksek olduğu firmaların ise büyük çoğunluğunun un ve dondurulmuş gida gibi zorunlu tüketim malzemeleri olarak sınıflandırılabilecek ürünleri üreten firmalar olduğu dikkati çekmektedir. Bu firmalar içinde hasılatı en çok yükselen firma ise Dardanel Önantaş Gıda Firması' dır. Yapılan incelemede firmanın ürettiği balık ürünlerinin tüketiminin Covid19 sürecinde iki kat arttığı, firmanın tarihinin en iyi çeyrek dönemini geçirerek konsolide satış gelirleri ve net kâr gibi verilerde kendi rekorunu kırdığı tespit edilmiştir (Ekonomist, 2020). COVID-19 tedbirleri kapsamında alınan sokağa çıkma kısıtlamaları ile toplumun genelinde gıda stoku yapma eğilimi görülmüştür. Bu dönemde insanlar kısıtlamaların uzun süreceği 
endişesi ile ihtiyacından fazla gıda satın alma davranışı göstermiştir. Bu durum gıda sektöründeki hasılat artışının nedenlerinden biri olarak düşünülebilir.

Tablo 15. Metal Eşya Makine Elektrikli Cihazlar Sektöründeki Firmalardan Hasılatı En Çok Düşen ve En Çok Artanlar

\begin{tabular}{|c|c|c|c|c|}
\hline \multirow[b]{2}{*}{ Kodu } & \multirow[b]{2}{*}{ Şirket Adı } & \multicolumn{2}{|c|}{ Hasılat (İlk 6 Ay) } & \multirow{2}{*}{$\begin{array}{c}\text { Değişim } \\
\text { (\%) }\end{array}$} \\
\hline & & 2020 & 2019 & \\
\hline EGEEN & Ege Endüstri & 195.384 .925 & 378.026 .782 & $-48,31$ \\
\hline FMIZP & Federal-Mogul İzmit Piston & 33.057 .543 & 56.999 .966 & $-42,00$ \\
\hline BFREN & Bocsh Fren & 72.408 .807 & 118.120 .034 & $-38,70$ \\
\hline SAFKR & Safkar Ege Soğutmacılık & 38.987.539 & 58.309 .887 & $-33,14$ \\
\hline KARSN & Karsan Otomotiv & 540.701 .000 & 758.666 .884 & $-28,73$ \\
\hline TMSN & Tümosan Motor & 256.917 .722 & 177.335 .804 & 44,88 \\
\hline BNTAS & Bandırma Ambalaj & 71.908 .732 & 49.478 .982 & 45,33 \\
\hline SILVR & Silverline Endüstri & 211.781 .922 & 136.780.182 & 54,83 \\
\hline FORMT & Formet Çelik Kapı Sanayi & 46.438 .263 & 29.527 .186 & 57,27 \\
\hline SAYAS & Say Yenilenebilir Enerji & 62.587 .780 & 19.126.992 & 227,22 \\
\hline
\end{tabular}

Tablo 9'a bakıldığında “Metal Eşya Makine Elektrikli Cihazlar” sektörü firmalarından 14'ünün hasılatında düşme meydana gelirken 18'da hasılat artışı olduğu görülmektedir. Hasılatı düşen firma sayısı ile artan firma sayısı birbirine yakın olup hasılatı düşen firmaların büyük çoğunluğu otomotiv firmaları, hasılatı artanların çoğunluğu ise beyaz eşya ve benzeri ürünler üreten firmalar oluşturmaktadır.

Sektörde en ciddi hasılat artışı elde eden firmanın ise Say Yenilenebilir Enerji firması olduğu görülmektedir. Say Yenilenebilir Enerji Firması ile ilgili yapılan araştırmada firmanın "güneş enerjisi sistemleri” üretimi yaptığı görülmüştür. Yapılan araştırmada Korona virüs salgınının güneş enerji sistemlerine olan ilgiyi artırdığı tespit edilmiştir (Habertürk, 2020). Bu durumun Say Yenilenebilir Enerji Firması' ndaki yüksek kar artışının nedenlerinden olduğu söylenebilir.

Tablo 16. Taş ve Toprağa Dayalı Üretim Sektöründeki Firmalardan Hasılatı En Çok Düşen ve En Çok Artanlar

\begin{tabular}{|l|l|r|r|r|}
\hline \multicolumn{1}{|c|}{ Kodu } & \multicolumn{1}{|c|}{ Şirket Adı } & \multicolumn{1}{c|}{ Hasılat (ilk 6 Ay) } & \multicolumn{1}{c|}{$\begin{array}{c}\text { Değişim } \\
\text { (\%) }\end{array}$} \\
\hline YBTAS & Yozgat İşçi Birliği İnşaat Malz. & 15.754 .024 & 23.229 .762 & $\mathbf{- 3 2 , 1 8}$ \\
\hline DENCM & Denizli Cam & 45.364 .026 & 65.227 .854 & $\mathbf{- 3 0 , 4 5}$ \\
\hline KUTPO & Kütahya Personel & 151.524 .279 & 194.216 .940 & $\mathbf{- 2 1 , 9 8}$ \\
\hline TRKCM & Trakya Cam & 2.713 .699 & 3.265 .583 & $\mathbf{- 1 6 , 9 0}$ \\
\hline NIBAS & Niğde Beton & 7.811 .816 & 8.937 .046 & $\mathbf{- 1 2 , 5 9}$ \\
\hline ANACM & Anadolu Cam & 2.432 .690 & 1.887 .194 & $\mathbf{2 8 , 9 1}$ \\
\hline EGSER & Ege Seramik & 257.802 .360 & 194.118 .820 & $\mathbf{3 2 , 8 1}$ \\
\hline
\end{tabular}




\begin{tabular}{|l|l|r|r|r|} 
USAK & Uşak Seramik & 222.280 .610 & 166.106 .703 & $\mathbf{3 3 , 8 2}$ \\
\hline BASCM & Başkent Çimento & 218.862 .987 & 133.179 .648 & $\mathbf{6 4 , 3 4}$ \\
\hline AFYON & Afyon Çimento & 122.209 .462 & 67.112 .693 & $\mathbf{8 2 , 1 0}$ \\
\hline
\end{tabular}

Tablo 9' a bakıldığında “Taş ve Toprağa Dayalı Üretim” sektörü firmalarından 7’nin hasılatında düşme meydana gelirken 15'nde hasılat artışı olduğu görülmektedir. COVID-19 döneminde sektördeki firmaların büyük çoğunluğunun satışlarında artış yaşanmıştır. Ancak Tablo 16'deki bilgilere bakıldığında hasılatı en çok düşen ve en çok artan firmalar arasında faaliyet alanı açısından yorumlanabilecek bir farklılık göze çarpmamaktadır. Sektörle ilgili finansal oranların ortalamalarında ise dikkat çekici durum "ADH” oranı bütün sektörlerde düşüş gösterirken Taş ve Toprağa Dayalı Üretim sektöründe artış göstermesidir.

Tablo 17. Orman Ürünleri ve Mobilya Sektöründeki Firmaların Hasılatındaki Değişim

\begin{tabular}{|c|c|c|c|c|}
\hline \multirow[b]{2}{*}{ Kodu } & \multirow[b]{2}{*}{ Şirket Adı } & \multicolumn{2}{|c|}{ Hasılat (İlk 6 Ay) } & \multirow{2}{*}{$\begin{array}{c}\text { Değişim } \\
\text { (\%) }\end{array}$} \\
\hline & & 2020 & 2019 & \\
\hline YONGA & Yonga Mobilya & 36.078 .120 & 41.286 .959 & $-12,62$ \\
\hline DGKLB & Doğtaş Kelebek Mobilya & 302.709 .442 & 344.243 .944 & $-12,07$ \\
\hline GENTS & Gentaş Dekoratif & 193.093 .969 & 190.624 .878 & 1,30 \\
\hline ORMA & Orma Orman Mahsulleri & 216.119 .915 & 201.081 .275 & 7,48 \\
\hline SUMAS & Sumaş Suni Tahta & 29.926 .837 & 27.226 .011 & 9,92 \\
\hline
\end{tabular}

BİST Orman Ürünleri ve Mobilya sektöründe 5 firma işlem görmekte olup Tablo 17'de görüldüğü gibi firmalarından 2'sinin hasılatında düşme meydana gelirken 3'ünde hasılat artışı olduğu görülmektedir. Taş ve Toprağa Dayalı Üretim sektörüne benzer şekilde bu firmaların faaliyet alanları açısından yorumlanabilecek bir farklılık bulunmamaktadır.

\section{SONUÇ}

COVID-19 olarak adlandırılan, ilk olarak Çin' de 2019' un sonlarına doğru ortaya çıkan, daha sonrasında Ortadoğu ve Avrupa'da, 2020 Mart ayında da Türkiye'de görülen salgının bütün Dünya'da birçok etkisi olmuştur. Bunlardan en önemlilerinden biri de salgının neden olduğu ekonomik ve finansal krizdir. 2020 yılının başından itibaren bu salgın hastalığın neden olduğu ekonomik ve finansal krize ilişkin çeşitli çalışmalar yapılmıştır.

$\mathrm{Bu}$ çalışmada COVID-19'un neden olduğu finansal krizin BİST İmalat Sektörü firmalarına olan finansal etkileri finansal oranlar yardımı ile tespit edilmeye çalışılmıştır. $\mathrm{Bu}$ amaçla istatistiki yöntem olarak Wilcoxon İşaretli Sıralar Testi uygulanmıştır. Test sonuçlarının daha iyi anlaşılabilmesi için firmaların aktif büyüklükleri dikkate alınarak finansal oranlardaki değişimin tartılı aritmetik ortalaması alınmış, iki dönem arasındaki hasılat değişimlerine ilişkin tablolar hazırlanmıştır. Yapılan analizler ve elde edilen sonuçları destekleyici diğer araştırmalar sonucunda COVID-19'un BİST İmalat sektörüne olan etkilerini aşağıdaki şekilde özetleyebiliriz: 
Genel itibariyle bütün sektörlerde UVYKO ile NO' nun aynı yönde arttığı görülmüştür. Yapılan araştırmada söz konusu dönemde COVID-19'un firmalar üzerindeki finansal etkilerini hafifletmek amaciyla kamu bankaları tarafindan sağlanan uzun vadeli kredilerin firmaların borç ödeyebilme gücünü artırdığı söylenebilir.

Bu dönemde genel itibarla İmalat Sektörü firmalarının hasılatlarında ve karlılıklarında düşüs olduğu görülmektedir. Alt sektörlerden en çok “Ana Metal Sanayii” ile "Tekstil, Giyim Eşyası ve Deri" sektörlerinin hasılatlarında ve dolayısıyla karlılık oranlarının düşüş göze çarpmaktadır. Bununla birlikte COVID-19 döneminin kendisine has özelliklerinin bazı sektörlerin ve firmaların pozitif olarak ayrışmasına neden olduğu görülmektedir. Özellikle COVID-19 tanı kiti satışı yapan RTA Laboratuvar Firması' ndaki kâr artışı salgının firmaya çok ciddi anlamda firsat oluşturduğunu göstermektedir. Bununla birlikte başta dezenfektan ve hijyen, ambalaj ürünleri üreten firmalar olmak üzere kişsisel bakım ürünleri üreten firmalar bu süreçten olumlu yönde etkilenmiştir. Uygulanan sokağa çıkma kısıtlamalarının Gıda Sektörü firmalarına olumlu etkisi gözlenirken, uzaktan eğitime geçilmesinin kâğıt ürünleri ve basılı yayınların satışlarının azalmasından dolayı Kâğıt Sektörünü olumsuz etkilediği söylenebilir.

Araştırma sonuçları ile özellikle önceki çalışmaların sonuçları incelendiğinde aralarında ciddi bir benzerlik olmadığı dikkat çekmektedir. Bunun nedeninin COVID-19'nun önceki krizler gibi doğrudan bir finansal kriz olmayıp bazı sektörleri olumsuz etkilerken dönemin özelliklerinden dolayı bazı sektörler için firsata dönüşmesi olduğu söylenebilir.

\section{KAYNAKLAR}

Abdioğlu, Hasan - Büyükşalvarcı, Ahmet - Dinç, Engin (2010), "Şirketlerin Mali Yapıları Üzerinde Ekonomik Krizlerin Etkileri: 2001 ve 2008 Ekonomik Krizleri Üzerine Bir Araştırma." Yönetim ve Ekonomik Araştırmalar Dergisi 14, ss. 27-58.

Akaytay, Ali - Çatı, Kahraman - Yücel, Serkan (2015), "Finansal Oranların Faaliyet Alanlarına Göre Değişiminin Merkez Bankası Sektör Raporları Yardımıyla İncelenmesi", Dumlupınar Üniversitesi Sosyal Bilimler Dergisi, Say1: 44, ss. 45-57

Anadolu Ajans1 (2020), https://www.aa.com.tr/tr/ekonomi/ekonomik-istikrar-paketi-tumkesimlere-kalkan-oldu/1795337 (14.12.2020)

Bahar, Ozan - İlal, Nur Çelik (2020), "Coronavirüsün (COVID-19) Turizm Sektörü Üzerindeki Ekonomik Etkileri”, International Journal of Social Sciences and Education Research, 6(1), ss. 108-122.

Bakır, Hasan - Şahin Cumhur (2009), Yöneticiler İçin Finansal Tablolar Analizi, Ankara, Detay Yayıncilik.

Balc1, Baki Riza (2012), “TFRS'lerin Finansal Analize Etkileri”, Journal of Yasar University, 28(7), ss. 4687- 4707.

Benli, Yasemin Keskin (2005), "Sektörel Farkl1lıkların Oranlar Üzerine Etkisi, Ampirik Bir Çalışma”, Gazi Üniversitesi Endüstriyel Sanatlar Eğitim Fakültesi Dergisi, Sayı:16, ss. 14-30. 
Berchin, Issa Ibrahim - Andrade - José Baltazar Salgueirinho Osório de (2020), "GAIA 3.0: Effects of the Coronavirus Disease 2019 (COVID-19) outbreak on sustainable development and future perspectives." Research in Globalization 2, 100014, pp. 1-5.

Çalış, Yıldırım Ercan - Çakır, Sibel (2019), “2014 ve Sonrası Finansal Dalgalanmaların BİST'te İşlem Gören İnşaat Sektörü Firmaları Üzerine Etkilerinin Finansal Oranlarla İncelenmesi”, İda Akademi Muhasebe ve Maliye Dergisi, Cilt: 2 Sayı: 2, ss. 202-221.

Çalışkan, Tuncer - Kerestecioğlu, Semih - Kara, Tülin (2011), "Finansal Krizin Gıda İşletmelerinin Finansal Yapısı Üzerine Etkileri", Yönetim ve Ekonomi Araştırmaları Dergisi 9 (16), ss. 68-84.

Çıtak, Nermin - Çalış, Y. Ercan (2020), “COVID-19 Salgının Turizm Sektörü Üzerine Olan Finansal Etkileri” Ida Academia Muhasebe ve Maliye Dergisi, 3(2), ss. 110-132.

Dalğar, Hüseyin - Kalkan Adnan - Kalkan, Yusuf (2012), "Ekonomik Krizlerin Gelişmiş ve Gelişmekte Olan Ülkelerdeki İşletmelerin Finansal Yapılarına Etkileri: İngiltereTürkiye Karşılaştırması”, Süleyman Demirel Üniversitesi İktisadi ve İdari Bilimler Fakültesi Dergisi, 17(3), ss.75-98.

Demir, Mahmut - Günaydın, Yusuf - Demir, Şirvan Şen (2020), "Koronavirüs (COVID-19) Salgınının Türkiye'de Turizm Üzerindeki Öncülleri, Etkileri Ve Sonuçlarının Değerlendirilmesi”, 1. International Journal of Social Sciences and Education Research, 6(1), ss. 80-107.

Ekonomist (2020), https://www.ekonomist.com.tr/soylesi/sektorde-dunyada-ilk-ucegirecegiz.html (16.12.2020)

Ekşi, İbrahim Halil (2010), "Firmaların Ölçekleriyle Krizden Etkilenme Düzeylerinin Karşılaştırılması: Tekstil Sektörü Örneği”, Atatürk Üniversitesi İktisadi ve İdari Bilimler D., Cilt: 24(4), ss. 65-78.

Ekşi, İbrahim Halil - Akçi Yavuz (2009), "Sektör Farklılıklarının Finansal Oranlar Üzerindeki Etkileri: İMKB İmalat Sanayi firmalarında Bir Uygulama”, Süleyman Demirel İİB Dergisi, 14(1), ss.115-126.

Euronews (2020) https://tr.euronews.com/2020/04/05/koronavirus-internetten-alisverisi nasil-etkiledi-en-cok-artan-ve-dusen-urunler-neler (16.12.2020)

Gider, Ömer (2011), “Ekonomik Kriz Dönemlerinin Özel Hastanelere Etkileri: Bir Özel Hastanenin Oran Analizleri Yöntemiyle Finansal Performansına Bakış”, Öneri Dergisi, 9(36), ss.87-103.

Gümüş, Umut Tolga - Şakar, Zekayi - Akkın, Gürkan - Şahin, Mustafa (2017), "Finansal Analizde Kullanılan Oranlar ve Firma Değer İlişkisi: BİST’de İşlem Gören Çimento Firmaları Üzerine Bir Analiz", Karadeniz Sosyal Bilimler Dergisi, 9(16), ss. 1-23. 
Gürsoy, Samet - Tunçel, Mert Baran - Sayar Burak (2020), "Koronavirüsün (COVID-19) Finansal Göstergeler Üzerine Etkileri”, Ekonomi Maliye İşletme Dergisi, 3(1), ss. 2032.

Habertürk. (2020). https://www.haberturk.com/adana-haberleri/79049206-koronavirus salgini-gunes-paneli-sistemlerine-ilgiyi-artirdi (16.12.2020)

Hacıevliyagil, Nuri - Şit, Ahmet (2016), "İmalat Sanayi Alt Sektörlerinde Sektör Farklı1ıklarının Finansal Oranlar Açısından Karşılaştırılması", Çankırı Karatekin Üniversitesi Sosyal Bilimler Enstitüsü Dergisi, 7(1): ss. 107-122.

İbiş, Salim (2020), "Covid-19 Salgınının Seyahat Acentaları Üzerine Etkisi. Safran Kültür ve Turizm Araştırmaları Dergisi”, 3(1): ss. 85-98.

İskenderoğlu, Ömer - Karakozak, Özlem (2013), “2008 Küresel Finansal Krizinin Finansal Oranlar Üzerine Etkisi: BIST' te İşlem Gören İmalat Sanayi İşletmeleri Üzerine Bir Uygulama”, Dokuz Eylül Üniversitesi İktisadi ve İdari Bilimler Fakültesi Dergisi, 28 (2), ss. 99-129.

İş ve İnşaat Makineleri Kümelenmesi. (2020), http://www.isim.org.tr/content/ upload/attached-files/covid-19-ekonomik-istikra 20200414170956. PDF (14.12.2020)

Karadeniz, Erdinç (2019), "Türkiye ve Rusya Arasındaki Uçak Krizinin Borsa İstanbul Turizm İşletmelerinin Finansal Performansına Etkilerinin Analizi”, Turizm Akademik Dergisi, 6(1), ss. 61-75.

Karadeniz, Erdinç - Koşan, Levent - Kahiloğulları, Selda - Zencir, Banu (2015), "Konaklama ve Yiyecek Hizmeti Faaliyetleri Alt Sektöründeki Küçük, Orta Ve Büyük Ölçekli İşletmelerin Likidite Durumunun Analizi”, Turizm ve Araştırma Dergisi, 4(2), ss.1827.

Kul, Seval (2014), "İstatistik Sonuçlarının Yorumu: P Değeri ve Güven Aralı̆̆ı Nedir? / Interpretation of Statistical Results: What is P Value and Confidence Interval?”, Plevra Bülteni, 8(1), ss. 1-3.

Müslümov, Alövsat - Karataş, Abdülmecit (2001), "The Effects of Asian Crisis to Turkish Manufacturing Industries: The Case of Cement, Food and Textile Industries", Doğuş Üniversitesi Dergisi, 2001/4.

Nueangnong, Visitsak - Hasan Subih, Abdulrahman Abdo Shawqi - Al-Hattami, Hamood Mohd (2020), The 2020's World Deadliest Pandemic: Corona Virus (COVID-19) and International Medical Law (IML), Cogent Social Sciences, 6(1), 1818936, pp. 1-13.

OECD (2020) "The Impact Of The Coronavirus (COVID-19) Crisis on Development Finance,"https://read.oecd-ilibrary.org/view/?ref=134_134569-xn1go1i113\&title= The-impact-of-the-coronavirus-(COVID-19)-crisis-on-developmentfinance (29.09.2020). 
Öztürk, Özkan - Şişman, Muhammet Yunus - Uslu, Hakan ve Çıtak, Ferhat (2020), "Effect of COVID-19 Outbreak on Turkish Stock Market: a Sectoral-Level Analysis”, Hitit University Journal of Social Sciences Institute, 13(1), ss. 56-68.

Sakarya, Betül (2006), “Türkiye'de Bankacılık Krizleri Nedenleri ve Regülasyon Uygulamaları", Yayınlanmamış Yüksek Lisans Tezi, Sakarya Üniversitesi Sosyal Bilimler Enstitüsü, Sakarya.

SASA. (2020), https://sasa.com.tr/haber/detay/polyester-devinin-uretimi-kovid-19-lamucadeleye-gore-sekillendi (14.12.2020)

Topaloğlu, Emre Esat (2014), “Finansal Krizlerin BİST Metal Eşya, Makina Endeksi’nde Faaliyet Gösteren Firmaların Mali Performanslarına Etkisinin Topsis Yöntemi İle Ölçülmesi”, Yönetim ve Ekonomi Araştırmaları Dergisi, 12(22), ss. 286-305.

Uyar, Ali - Okumuş, Ersin (2010), "Finansal Oranlar Aracılığıyla Küresel Ekonomik Krizin Üretim Şirketlerine Etkilerinin Analizi: İMKB'de Bir Uygulama", Muhasebe ve Finansman Dergisi, 46, ss.146-156.

Uzmanpara (2020), https://uzmanpara.milliyet.com.tr/kap-haberi/rtalb-rta-laboratuvarlari biyolojik-urunler-ilac-ve-makine-sanayi-ticaret-a-s--ozel-durum-aciklamasigenel/1535768/ (15.12.2020)

Vural, Gamze - Uçar, Halil İbrahim (2017), "Krizlerin Türk Turizm Sektörünün Finansal Durumuna Ve Piyasa Duyarlılığına Etkisi: 1999-2015 Dönemi Üzerine Bir Uygulama” Ç.Ü. Sosyal Bilimler Enstitüsü Dergisi, 26(3), ss. 257-271.

WHO (World Healt Organization) (2020), Coronavirus disease 2019 (COVID19) Situation Report - 51, https://www.who.int/docs/defaultsource/coronaviruse/ situation-reports/20200311-sitrep-51-covid- 19.pdf?sfvrsn=1ba62e57_10. (29.09.2020).

Worldometers (2020), https://www.worldometers.info/coronavirus/ (17.12.2020)

Zeren, Feyyaz - Hizarc1, Atike (2020), "The Impact of COVID-19 Coronavirus on Stock Markets: Evidence from Selected Countries” Muhasebe ve Finans İncelemeleri, 3(1), ss. 78-84. 
